\title{
Control chart applications in healthcare: a literature review
}

\author{
Gaurav Suman and DeoRaj Prajapati* \\ Department of Mechanical Engineering Punjab Engineering College (Deemed to be University), Chandigarh 160012, India
}

Received: 13 December 2017 / Accepted: 19 February 2018

\begin{abstract}
The concept of Statistical process control (SPC) was given by the physicist Walter Shewhart in order to improve the industrial manufacturing. The SPC was firstly applied in laboratory and after then shifted to patient level in hospitals. As there is more involvement of human in healthcare, the chances of errors are also more. SPC i.e., control chart can help in determining the source of errors by identifying the special and common causes of variations. This paper presents the review of literature on the application of SPC and control chart in healthcare sector. Forty articles are selected out of 142 potentially relevant searched studies. Selected studies are categorised into eight departments. Literature survey shows that most of work on control chart applications in healthcare is carried out in Surgery, Emergency and Epidemiology departments. US, UK and Australia are the main customers where maximum amount of work was done. The US is the country where control chart in healthcare sector have been used at regular interval. This shows the gap of deploying control chart in different departments and different countries as well. The CUSUM and EWMA chart came into picture in healthcare sector after 2008 and are used at regular interval.
\end{abstract}

Keywords: statistical process control / control charts / healthcare sector / countries / departments

\section{Introduction}

Quality in healthcare is always a big concern because bad quality in healthcare can make a difference in terms of life or death of patients. The investment is continuously growing in this sector with little interest towards quality. The importance of building safe and effective healthcare system was realised in 2000 because several reports issued by US Institute of Medicine as reported by Lazarus and Neely [1]. In one of his report, released in November 1999, the authors estimated that around 98,000 patients die each year due to medical errors. According to Department of Health (2001) [2] \& Milligan and Robinson [3], due to adverse incidents and clinical negligence claim, an estimated $£ 400$ million is being paid which caused approximately $£ 2$ billion per annum. Arthur [4] reported the following statistics:

- one percent of patients will die because of medical errors; - six percent of patients will be disabled permanently because of medical mistakes;

- fifteen diagnoses out of every 100 are incorrect;

- twenty to fifty out of 100 diagnostic procedures should never have been done because their results did not help to diagnose patients;

- five to ten out of every 100 admitted patients get infected during treatment.

\footnotetext{
* Corresponding author: prajapatimed@gmail.com
}

These all data illustrate that there is a need to monitor and control the healthcare performance so that adverse events can be minimized. Healthcare system needs both investment as well as quality to meet the ultimate objective of patient satisfaction. As healthcare is a service organisation and every organisation wants to boost up their revenue while decreasing cost by providing appropriate quality in the services. In order to attain the quality objectives, quality initiative like statistical process control (SPC) will be very effective.

The aim of this paper is to provide the guidance in the direction of implementing control charts in healthcare. The various studies show applications of the control charts in various departments. This paper provides the information about departments and countries; where these studies have been done. Statistical analysis shows the frequency of these charts used in healthcare.

\subsection{Statistical process control}

Statistical process control (SPC) techniques have played an efficacious role in monitoring hospital performance such as mortality rate, pre and post-operative complications, number of infections in hospital etc. as reported by Finison et al. [5], Finison and Finison [6], Benneyan [7], Maccarthy and Wasusri [8], Clemente et al. [9]. The concept of SPC was given by the Walter A Shewhart in order to improve the industrial manufacturing processes. The SPC was 
firstly applied in laboratory and after that shifted to patient level in hospital. As there is more involvement of human in healthcare, the chances of errors are also more. SPC can help in determining the source of errors by identifying the special and common causes of variations.

SPC is a system of online quality control and can be defined as a philosophy, strategy and methods for the improvement of systems, outcomes and processes. The SPC is based on theory of variation i.e., common and special causes of variations. It involves the concept of process thinking, learning through data, analytical study, experimentation, measurement system and methods of data collection as reported by Ning et al. [10]. The most commonly used charts in SPC are run charts, mean chart, range chart, histogram, Pareto chart etc. One thing should be noted that SPC and statistical quality control are often used reciprocally but the later one is used to describe the extensive management approach towards quality management.

The present paper deals with department wise review of control charts applications in healthcare. Control chart is primary tool in SPC and is commonly used for monitoring and improvement of on-going process. The sample $u$ control chart is shown in Figure 1.

In order to construct a control chart, first of all, there should be availability of data. Data can be of two types i.e., variable and attribute. The data which can be measured on some scale comes under the category of variable and on the other hand, the data which cannot be measured and represented on count basis comes under attribute. Figure 1 shows the data of attribute type control chart. There are three lines in control chart i.e., Centre line, upper control limit and lower control limit. Upper and lower control limits are at a distance of 3 standard deviations from the centre line. A set of decision rule was suggested in that a process is out of control and these are:

- if any point lies beyond the specified three sigma control limits;

- if two out of three consecutive points fall beyond the two sigma control limits;

- if four out of five consecutive points fall beyond the one sigma control limits;

- if the run of eight consecutive points fall on either side of centre line.

According to the types of data, there are two types of control chart i.e., control chart for variables and control chart for attributes. The data is arranged into subgroup in order to establish a set of reading in which process shows stable and controlled behaviour. For example, we can choose to group response time readings taken at regular intervals throughout the day into a subgroup which is then plotted as a single point on a control chart. In attribute chart, there is count of defects or defectives. In one defective unit, there may be several defects. Control charts can be classified as $\bar{X} \& \mathrm{~S}$ charts, $\bar{X} \& \mathrm{R}$ charts, p chart and np chart etc. The details about construction and use of control chart are given by Kaminsky et al. [11] and Amin [12]. Thor et al. [13] discussed the variables used in clinical monitoring, benefits and barrier associated with control chart use. According to Koetsier et al. [14], the maximum numbers of charts are plotted on two phases of the PDSA

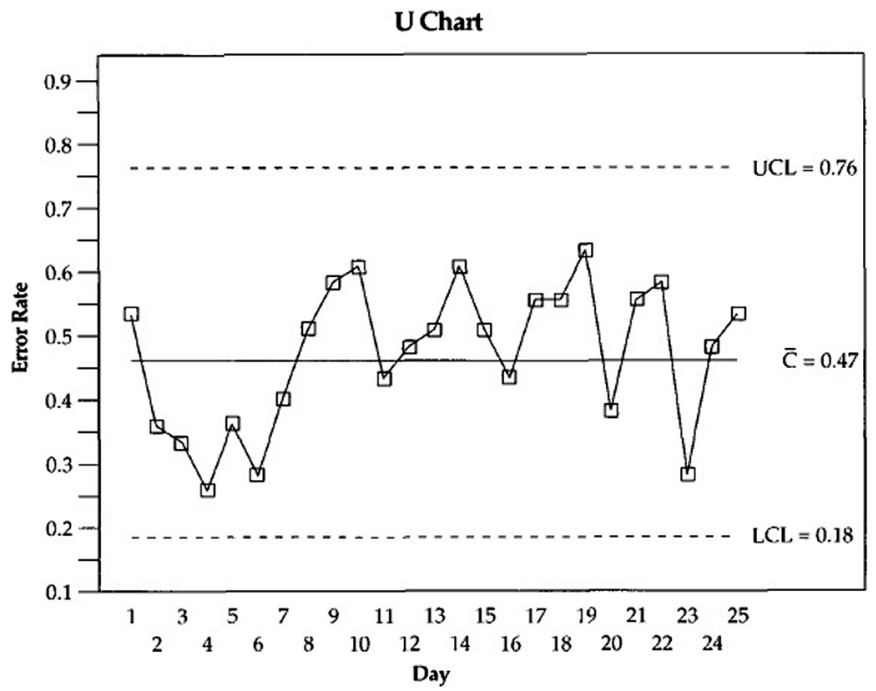

Fig. 1. Sample u chart for No. of defects/unit, given by Finison et al. (1993).

cycle. Laney [15] and Mohammed \& Laney [16] suggested control chart for attributes for very large sample sizes (in thousands or even millions). Prajapati [17] presented modified $\bar{X}$ chart for autocorrelated observations. Depending upon the suitability of charts; they can be used for a particular situation. Figure 2 shows the detailed classification of control charts.

In addition to above charts, there are other charts like CUSUM (Cumulative Sum Chart) and EWMA (Exponential Weighted Moving Average Chart). These charts come under the category of Control chart for variables. These charts come into picture because the above mentioned control charts are not sensitive enough for the process measurement. The detail about construction and use of CUSUM and EWMA chart is given by Woodall et al. [18]. Pillet et al. [19] stated that multivariate chart is used when more than one variable are to be monitored. Most of studies on the application of control chart in healthcare are carried out in US as reported by Seddon et al. [20]. The present paper deals with department wise review of control charts applications in healthcare sector. First section deals with introduction to SPC and control charts while Section 2 describes the methodology. The detailed literature survey in Emergency, Surgery, Epidemiology, Radiology, Pulmonary, Cardiology, Administration and Pharmaceutical departments in tabular form are presented in Section 3. Section 4 provides the statistical analysis and discussion on the results of statistical analysis is given in Section 5 . Limitations of studies are discussed in Section 6 and managerial and academic implications are presented in Section 7. The final conclusion of the paper provided in Section 8.

\section{Methodology}

The extensive research is done to find out the articles related to control charts applications in healthcare sector. The Pubmed, EBSCO, ResearchGate and Google Scholar databases have been used to find the studies; describing the use of 


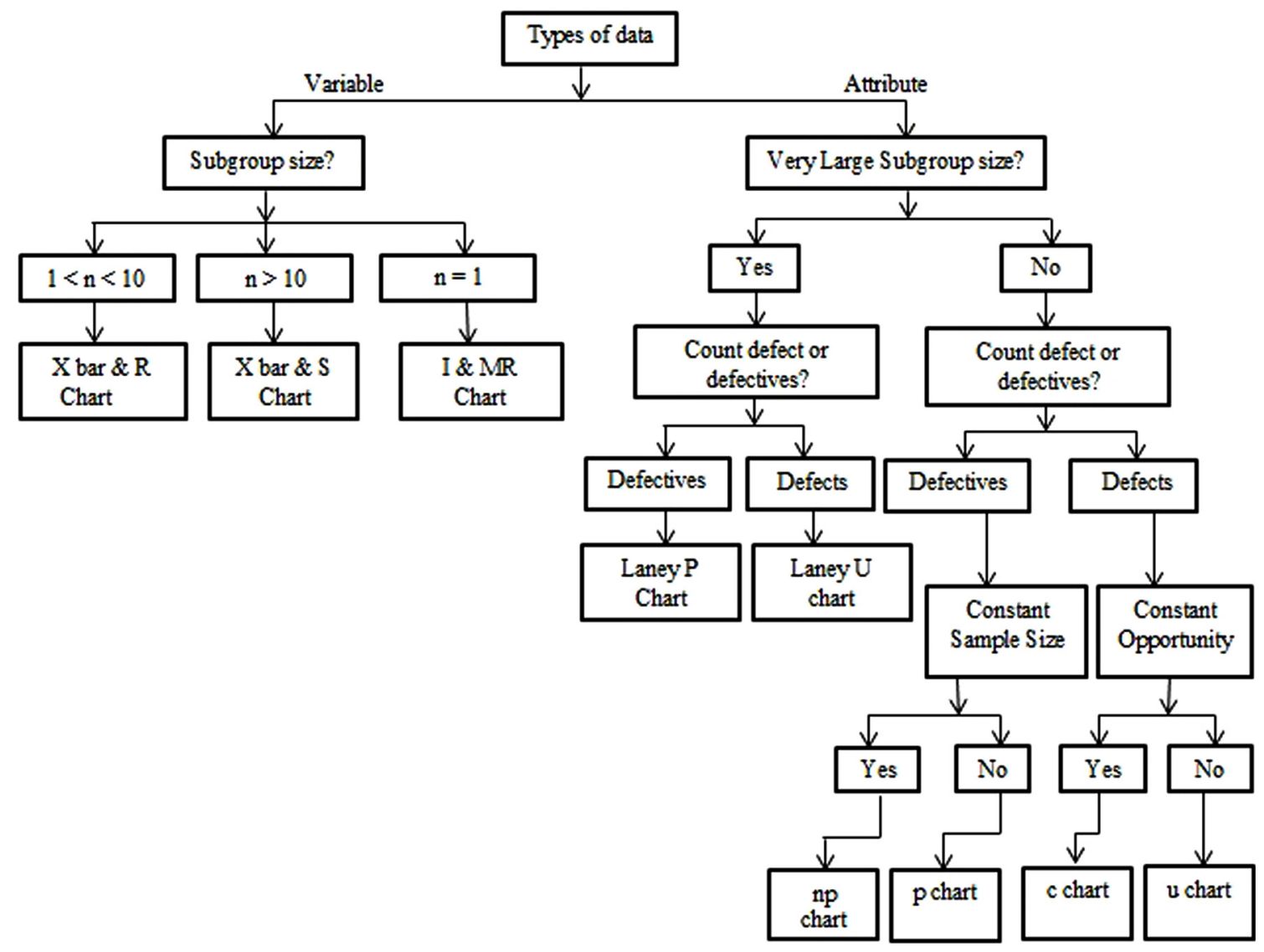

Fig. 2. Classification of control charts.

control chart in the specific departments of the healthcare. The 'SPC', 'Control chart', 'Application' and 'Healthcare' are the key words in the search. The search excluded master and doctoral dissertation since there is greater possibilities of these studies to appear in academic and professional Journals.

The criteria for the inclusion of research papers is that control chart should be applied at departmental level. Figure 3 shows the flow chart for selection of studies. Initially 142 potentially relevant articles are identified. Out of which, 92 articles are removed by studying abstract because most of them were irrelevant, review papers and tutorials. The 50 research papers are selected for full study. Out of which 40 studies are included in the review as shown in Figure 3.

\section{Survey of literature}

The literature survey is divided according to the departments in healthcare. Forty studies were found over eight departments i.e. Emergency, Surgery, Epidemiology, Radiology, Cardiology, Pulmonary, Administration and Pharmaceutical. The details about the included research papers is arranged in tabular form showing the details of work done, types of chart, variables used, country and types of study.

\subsection{Studies done in Emergency department}

Emergency department is always associated with longer waiting time, length of stay, longer turnaround time and overcrowded room. So there is always scope for the improvement in Emergency department. Table 1 shows the details of work done, types of charts, variables used, types of study and country along with authors' name and year. Seven numbers of studies have been included in Emergency department. It is clear from Table 1 that EWMA is the mostly used chart and 'Mortality rate' is mainly used variable in Emergency department.

\subsection{Studies done in Surgery department}

The Surgery department is often overburdened with errors and inefficiencies like surgical site infections, pre and post-operative complications etc. Table 2 shows the details of work done, types of chart, variables used, types of study and country along with authors' name and year. Nine numbers of studies have been included in the Surgery department. It is clear from Table 2 that run chart, CUSUM chart and $\mathrm{p}$ chart have been mostly used in surgery department. Mortality rate, length of stay and complications are often used variable. 


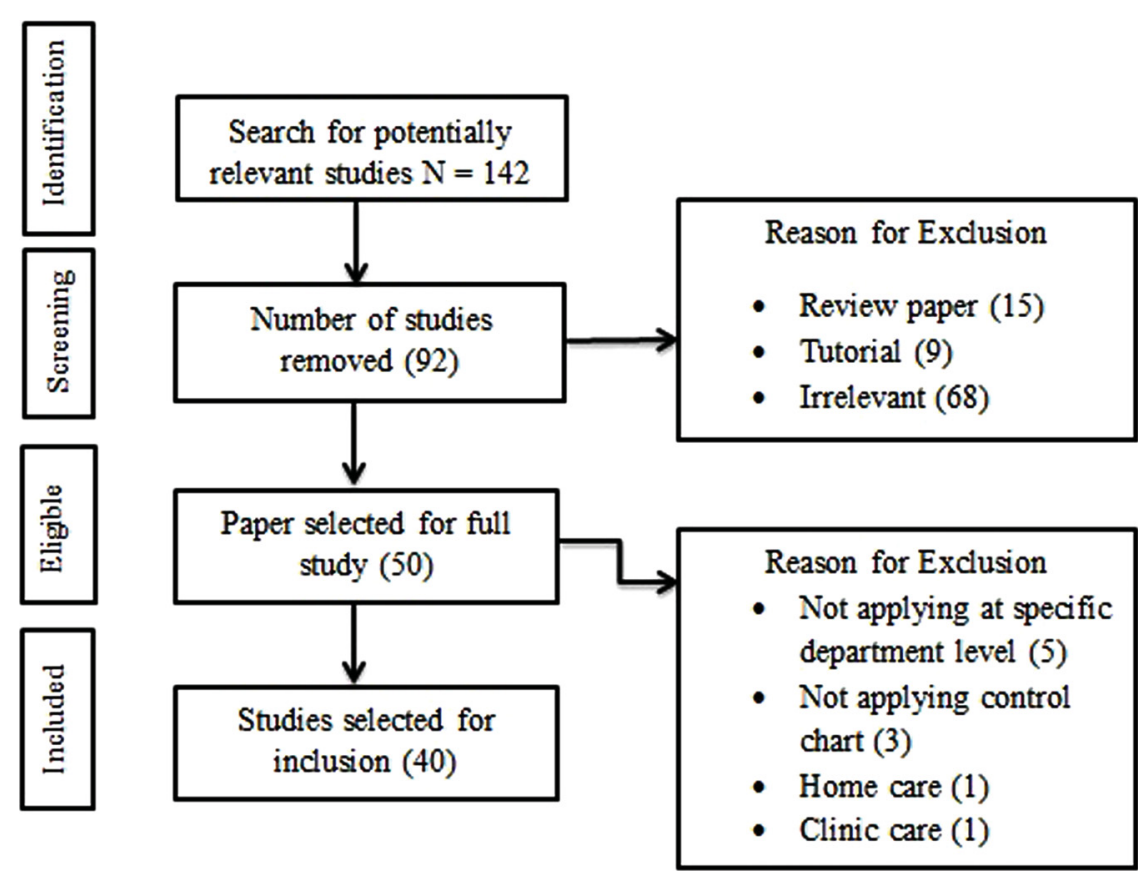

Fig. 3. Flow chart for selection of studies.

\subsection{Studies done in Epidemiology departments}

The Epidemiology takes into consideration the effects of disease and health condition of particular patients in the defined population. In simple terms, this department take care of infections related to particular disease or health condition. The numbers of cases with infections per thousand patients' days are generally very less. This is the reason that $\mathrm{p}$ chart is most commonly used in Epidemiology departments. Table 3 shows the details of work done and types of charts used along with authors' name and year. Nine numbers of studies have been included in Epidemiology department. Sellick [21] and Morton et al. [22] used various types of control charts like CUSUM, EWMA, p, c, u charts etc. for detection and monitoring of hospital acquired infections in Epidemiology department.

\subsection{Studies done in Radiology departments}

The use of X-rays and other high energy radiation for treatment and diagnosis of disease comes under the Radiology department. Table 4 shows the details of work done, types of chart, variables used, types of study and country along with authors' name and year. Five numbers of studies have been included in Radiology department.

\subsection{Studies done in Pulmonary departments}

The branch of medicine that deals with causes, diagnosis, prevention and treatment of various diseases that affects the lungs comes under Pulmonary. Table 5 shows the details of work done, types of chart, variables used, types of study and country along with authors' name and year. Two numbers of studies have been included in Pulmonary department.

\subsection{Studies done in Cardiology departments}

The Cardiology department deals with diseases and an abnormality of human's heart. Table 6 shows the details of work done, types of chart, variables used, types of study and country along with authors' name and year. Two numbers of studies have been included in Cardiology department.

\subsection{Studies done in Administration departments}

Table 7 shows the details of work done, types of chart, variables used, types of study and country along with authors' name and year. Three numbers of studies have been included in Administration department.

\subsection{Studies done on Pharmactuel department}

Table 8 shows the details of work done and types of charts used along with authors' name and year. Three numbers of studies have been included in Pharmactuel department.

\section{Statistical analyses}

As stated earlier, 40 suitable research papers out of 142 potentially relevant searched articles have been identified for this study. Generally the statistical analysis can be defined as collection, examination and interpretation of quantitative data in order to find trends, relationships and underlying causes. The bar chart and Matrix plot are utilized for the statistical analysis. Analyses of studies are categorised into following sub-sections. 
Table 1. Literature survery in Emergecny department

\begin{tabular}{|c|c|c|c|c|c|}
\hline $\begin{array}{l}\text { Authors } \\
\text { and Year }\end{array}$ & Details of work done & Types of chart & Variables & Types of study & Country \\
\hline $\begin{array}{l}\text { Kaminsky } \\
\text { et al. [23] }\end{array}$ & $\begin{array}{l}\text { Recommended the use of SPC to } \\
\text { analyse the quality indicators in } \\
\text { healthcare organizations. The use } \\
\text { and interpretation of p chart was } \\
\text { preferred. The examples of use of } \\
\text { SPC for number of patients } \\
\text { leaving Emergency departments } \\
\text { and number of birth with } \\
\text { caesarean were shown. }\end{array}$ & p chart & $\begin{array}{l}\text { Number of } \\
\text { patients leaving } \\
\text { ED, Number of } \\
\text { birth with } \\
\text { caesarean }\end{array}$ & $\begin{array}{l}\text { Retrospective } \\
\text { Study }\end{array}$ & US \\
\hline $\begin{array}{l}\text { Callahan } \\
\text { and Griffen [24] }\end{array}$ & $\begin{array}{l}\text { Recommended the use of SPC to } \\
\text { reduce door to reperfusion time of } \\
\text { patients. After the successful } \\
\text { intervention, it was found that } \\
\text { there was run of } 14 \text { data points } \\
\text { below the centre line which } \\
\text { showed huge improvement in the } \\
\text { process. The efforts were in right } \\
\text { direction and helpful in reducing } \\
\text { the door to reperfusion times. } \\
\text { Initially the upper control limit of } \\
\text { data was } 206 \text { minutes which was } \\
\text { reduced to } 140 \text { minutes. }\end{array}$ & $\mathrm{X}$ bar chart & $\begin{array}{l}\text { Door to } \\
\text { reperfusion time }\end{array}$ & $\begin{array}{l}\text { Longitudinal } \\
\text { Study }\end{array}$ & US \\
\hline $\begin{array}{l}\text { Gilligan } \\
\text { and Walters [25] }\end{array}$ & $\begin{array}{l}\text { Reduced the hospital mortality } \\
\text { rate by reducing medical errors } \\
\text { and timely interventions to } \\
\text { facilitate flow of patient. After } \\
\text { intervention, there was punctuality } \\
\text { in daily senior medical review and } \\
\text { in planning of discharge. The early } \\
\text { warning training allowed reducing } \\
\text { the mortality rate in Emergency } \\
\text { department which is reflected in } \\
\text { hospital standardised mortality } \\
\text { rate. }\end{array}$ & $\begin{array}{l}\text { Run chart and } \\
\text { CUSUM }\end{array}$ & $\begin{array}{l}\text { Mortality rate, } \\
\text { Medical outliers }\end{array}$ & $\begin{array}{l}\text { Longitudinal } \\
\text { Study }\end{array}$ & UK \\
\hline Minne et al. [26] & $\begin{array}{l}\text { The authors made use of SPC in } \\
\text { order to validate a classification } \\
\text { tree model for estimating } \\
\text { mortality rate. It was investigated } \\
\text { that proposed tree model did not } \\
\text { provide the reliable results and } \\
\text { hence could not be used for } \\
\text { purpose of benchmarking. It } \\
\text { should be noted that in order to } \\
\text { identify the high risk subgroup, at } \\
\text { least two out of three pre- } \\
\text { identified subgroups could be } \\
\text { used. }\end{array}$ & EWMA & Mortality rate & $\begin{array}{l}\text { Retrospective } \\
\text { Study }\end{array}$ & Netherlands \\
\hline Moran et al. [27] & $\begin{array}{l}\text { Implemented Statistical Process } \\
\text { Control (SPC) to control the } \\
\text { mortality in the intensive care }\end{array}$ & EWMA & Mortality rate & $\begin{array}{l}\text { Retrospective } \\
\text { Study }\end{array}$ & Australia \\
\hline
\end{tabular}
mortality in the intensive care society of Australia and New Zealand. Initially the average raw mortality was $14.07 \%$. The raw average and standard deviation for mortalities ranged from 0.012 and 0.113 to 0.296 and 0.457 respectively whereas the expected mortality average and standard deviation ranged from 0.013 and 0.045 to 0.278 and 0.247 respectively. Out of control 
Table 1. (continued).

\begin{tabular}{|c|c|c|c|c|c|}
\hline $\begin{array}{l}\text { Authors } \\
\text { and Year }\end{array}$ & Details of work done & Types of chart & Variables & Types of study & Country \\
\hline & $\begin{array}{l}\text { signalling was shown for raw } \\
\text { mortality series in risk adjusted } \\
\text { exponential weighted moving } \\
\text { average chart. It was } \\
\text { recommended to hospital to } \\
\text { investigate the assignable causes } \\
\text { of variations. }\end{array}$ & & & & \\
\hline $\begin{array}{l}\text { Harrou } \\
\text { et al. [28] }\end{array}$ & $\begin{array}{l}\text { Decreased the time for detection } \\
\text { of abnormal daily patient arrivals } \\
\text { at the Paediatric Emergency } \\
\text { department. Auto regressive } \\
\text { moving average model was used } \\
\text { to analyse the data collected } \\
\text { during January-December } 2011 \text {. } \\
\text { The used model provided positive } \\
\text { results in terms of detection of } \\
\text { abnormal patient arrivals. The } \\
\text { benefit of early detection of } \\
\text { abnormal situations was to } \\
\text { encourage the control of these } \\
\text { conditions. }\end{array}$ & EWMA & Daily attendance & $\begin{array}{l}\text { Retrospective } \\
\text { Study }\end{array}$ & France \\
\hline $\begin{array}{l}\text { Pagel } \\
\text { et al. [29] }\end{array}$ & $\begin{array}{l}\text { The authors found the initial and } \\
\text { final point of winter surge in } \\
\text { intensive care unit. Initially the } \\
\text { optimal Bollinger band thresholds } \\
\text { were found to be } 1.2 \text { and } 1 \\
\text { standard deviation above and } \\
\text { below of } 41 \text { day demand moving } \\
\text { average respectively. In the end, } \\
\text { positive results were obtained as } \\
\text { surge was identified from 18th } \\
\text { November } 2013 \text { to } 4 \text { th January } \\
2014 \text {. }\end{array}$ & Run chart & $\begin{array}{l}\text { Demand for } \\
\text { retrieval }\end{array}$ & $\begin{array}{l}\text { Retrospective } \\
\text { Study }\end{array}$ & UK \\
\hline
\end{tabular}

\subsection{Analysis of studies using bar chart}

The range of number of studies included from different years is shown in Figure 4. It is clear from Figure 4 that 25 out of 40 studies are from year 2009 onwards. Figure 4 shows bar chart for range of number of studies. Figure 5 shows the number of included studies from different departments. Most of the work is carried out in Emergency, Surgery and Epidemiology department. A little amount of work is done on Cardiology and Pulmonary departments. Figure 6 shows the number of studies selected from different countries. It is found that most of work on control chart applications in healthcare is carried out in US, UK and Australia.

In healthcare applications, p chart, run chart, CUSUM and EWMA are mostly used as shown in Figure 7. Figure 8 shows the longitudinal and retrospective types of studies. It is clear from the figure that the most of the work is done on retrospective studies.

\section{Analysis of studies using matrix plot}

Matrix plot is a graph that can be used to find the relationship among different pairs of variable at the same time. It can also be defined as set of individual scatter plots.
These are two types: matrix of plots and each Y verses each $\mathrm{X}$.

Figure 9 shows the distribution of number of studies in different departments across the time line starting from 1996 to 2017. The different rows in Figure 9 show the different departments. $\mathrm{X}$ axis shows the year of studies; while $\mathrm{Y}$ axis shows the number of studies in a particular year.

Figure 10 shows the distribution of number of studies in differnet countries across the time line. It can be concluded from Figure 10 that conrol charts have been used in US regularly. The number of studies employing different types of chart across the time line are shown in Figure 11. It is evident from Figure 11 that $\mathrm{p}$ chart, run chart and X bar chart in healthcare have been used very frequently.

\section{Results and discussions}

The control charts have been proved to be magnificent tools in improving the quality of healthcare industry since last three decades. The control charts were firstly applied in laboratory and after then shifted to patient level in hospitals. There are astounding results in terms of decrease in mortality rate, door to reperfusion time, door to needle 
Table 2. Literature survery in Surgery department

\begin{tabular}{|c|c|c|c|c|c|}
\hline $\begin{array}{l}\text { Author } \\
\text { and Year }\end{array}$ & Details of work done & Types of chart & Variables & Types of study & Country \\
\hline $\begin{array}{l}\text { Levett } \\
\text { and Carey [30] }\end{array}$ & $\begin{array}{l}\text { Presented various examples of SPC } \\
\text { to monitor the coronary artery } \\
\text { bypass grafting mortality, length of } \\
\text { stay and admission rate in intensive } \\
\text { care unit. The authors ended up } \\
\text { with conclusion that control charts } \\
\text { allow making the process stable by } \\
\text { detecting and eliminating the special } \\
\text { or assignable causes of variations. }\end{array}$ & $\bar{X}$ Chart & $\begin{array}{l}\text { Mortality rate, } \\
\text { length of stay } \\
\text { and admission } \\
\text { time }\end{array}$ & $\begin{array}{l}\text { Longitudinal } \\
\text { study }\end{array}$ & US \\
\hline Mohammed [31] & $\begin{array}{l}\text { Recommended the use of statistical } \\
\text { process control to improve the } \\
\text { quality of healthcare. The examples } \\
\text { surgeon specific mortality rate } \\
\text { following colorectal cancer surgery } \\
\text { was presented with the help of } X \\
\text { chart. In addition, background } \\
\text { feature of control chart and how it } \\
\text { transformed to healthcare were also } \\
\text { provided. }\end{array}$ & $\bar{X}$ Chart & Mortality rate & $\begin{array}{l}\text { Retrospective } \\
\text { study }\end{array}$ & UK \\
\hline $\begin{array}{l}\text { Duclos } \\
\text { and Voirin [32] }\end{array}$ & $\begin{array}{l}\text { Provided essential points on how to } \\
\text { develop and interpret SPC for } \\
\text { healthcare practice. The } \\
\text { implementation of p chart into } \\
\text { healthcare practice required the } \\
\text { thorough investigation of the root } \\
\text { causes of the variations identified. } \\
\text { The every quality initiative was } \\
\text { must supported by the top } \\
\text { management to be successful. } \\
\text { Implementation of p chart also } \\
\text { encouraged the healthcare } \\
\text { practitioner to do self-examination of } \\
\text { the care delivered. }\end{array}$ & p chart & $\begin{array}{l}\text { Number of } \\
\text { complication }\end{array}$ & $\begin{array}{l}\text { Retrospective } \\
\text { study }\end{array}$ & France \\
\hline $\begin{array}{l}\text { Jones } \\
\text { and Steiner [33] }\end{array}$ & $\begin{array}{l}\text { Determined the performance of risk } \\
\text { adjusted CUSUM chart in the } \\
\text { presence of estimation error. } \\
\text { Estimation error effect on risk } \\
\text { adjusted CUSUM chart performance } \\
\text { was evaluated and found to have } \\
\text { significant effect in terms of } \\
\text { variation of true average run length } \\
\text { (ARL). It is estimated that main } \\
\text { source of estimation error was the } \\
\text { overall adverse event. }\end{array}$ & CUSUM Chart & $\begin{array}{l}\text { Mortality rate of } \\
30 \text { days }\end{array}$ & $\begin{array}{l}\text { Longitudinal } \\
\text { study }\end{array}$ & Australia \\
\hline Smith et al. [34] & $\begin{array}{l}\text { The authors checked the daily } \\
\text { morbidity and mortality review of } \\
\text { surgical process at a single site. The } \\
\text { variables like length of stay or } \\
\text { readmission less than } 28 \text { days, } \\
\text { bypass duration, acute pre and post- } \\
\text { procedural complications etc. were } \\
\text { found to be suitable for monitoring } \\
\text { healthcare outcomes. The special } \\
\text { causes of variation were evaluated } \\
\text { deeply and assigned to variations in } \\
\text { healthcare practice as well as } \\
\text { individual performance. }\end{array}$ & CUSUM and EWMA & $\begin{array}{l}\text { Length of stay, } \\
\text { complications. }\end{array}$ & $\begin{array}{l}\text { Longitudinal } \\
\text { study }\end{array}$ & Australia \\
\hline Keller et al. [35] & $\begin{array}{l}\text { Initiated the SPC in order to identify } \\
\text { the length of stay (LOS) outliers and }\end{array}$ & Run Chart & Length of Stay & $\begin{array}{l}\text { Retrospective } \\
\text { study }\end{array}$ & US \\
\hline
\end{tabular}
improvement. The out of control 
Table 2. (continued).

\begin{tabular}{|c|c|c|c|c|c|}
\hline $\begin{array}{l}\text { Author } \\
\text { and Year }\end{array}$ & Details of work done & Types of chart & Variables & Types of study & Country \\
\hline & $\begin{array}{l}\text { points were identified and these } \\
\text { points indicated longer operating } \\
\text { times and temporary nursing at } \\
\text { discharge. Higher readmission rate } \\
\text { was identified for outliers as } \\
\text { emergent open, emergent lap and } \\
\text { elective lap. }\end{array}$ & & & & \\
\hline $\begin{array}{l}\text { Oguntunde } \\
\text { et al. [36] }\end{array}$ & $\begin{array}{l}\text { Identified the importance of SPC to } \\
\text { healthcare with application of real } \\
\text { data set. The XMR control chart } \\
\text { from the previous study showed that } \\
\text { only one sample point was outside } \\
\text { the upper control limit (i.e Surgeon } \\
\text { H) while the p-chart in this article } \\
\text { reveals that three sample points (i.e., } \\
\text { Surgeons E, H and J) were outside } \\
\text { the upper control limit. Surgeons } \\
\text { corresponding to sample points } \\
\text { outside the control limits were } \\
\text { hazardous to the patients as well as } \\
\text { to the health institution. }\end{array}$ & p chart & $\begin{array}{l}\text { Proportions of } \\
\text { death }\end{array}$ & $\begin{array}{l}\text { Retrospective } \\
\text { study }\end{array}$ & Nigeria \\
\hline $\begin{array}{l}\text { Woodall } \\
\text { et al. [37] }\end{array}$ & $\begin{array}{l}\text { The authors made use of SPC to } \\
\text { reduce surgical site infections and } \\
\text { mortality. The positive results were } \\
\text { obtained as the reduction in } \\
\text { mortality rate from } 3.7 \% \text { to } 1.8 \% \\
\text { which shows approximately } 50 \% \\
\text { decline in mortality rate. According } \\
\text { to the hospital administrative } \\
\text { department, approximately } 20,000 \\
\text { surgical procedure were carried out } \\
\text { in a year and decrease in mortality } \\
\text { rate caused approximately saving of } \\
300 \text { lives. }\end{array}$ & Run Chart & $\begin{array}{l}\text { Rate of surgical } \\
\text { site infections } \\
\text { and } 30 \text { day } \\
\text { mortality }\end{array}$ & $\begin{array}{l}\text { Longitudinal } \\
\text { study }\end{array}$ & US \\
\hline $\begin{array}{l}\text { Schrem } \\
\text { et al. [38] }\end{array}$ & $\begin{array}{l}\text { Determined the utility of } G \text { chart for } \\
\text { healthcare process control. G chart } \\
\text { examined the changes in detection } \\
\text { rate of cancer during aftercare and } \\
\text { no significant relation was found } \\
\text { with identified risk factor for cancer } \\
\text { free survival i.e., showing p value } \\
\text { less than } 0.05 \text {. There was increment } \\
\text { in SIR for renal cell carcinoma } \\
(\mathrm{SIR}=22.46 \text { ) and post-transplant } \\
\text { lymph proliferative disorder } \\
(\mathrm{SIR}=8.36) \text {. }\end{array}$ & G chart & $\begin{array}{l}\text { Site Specific } \\
\text { standardized } \\
\text { incidence ratio } \\
\text { (SIR) }\end{array}$ & $\begin{array}{l}\text { Retrospective } \\
\text { study }\end{array}$ & Germany \\
\hline
\end{tabular}

time, length of stay, processing time, admission time, complications, surgical site infections, percentage of errors etc. in almost every department of the hospital. One thing should be noted that implementation of control charts does not automatically leads to process improvement. There is responsibility of top management along with staff associated with the process to find the special causes of variation and rectify them. In this way, the management system needs to be flexible for making the required changes.

The present paper deals with control chart applications in healthcare. The extensive research is done to find out the articles related to the control chart in healthcare.
Out of 142 relevant articles identified, 40 have been found to be more relevant for the study. The criteria for the inclusion of research papers are that control charts should be applied at departmental level. Most of the included studies i.e. 25 out of 40 are from year 2009 onwards as indicated in Figure 4. This shows that application of control charts in healthcare is continuously increasing from nineties to 2017.

It is evident from Figure 5 that most of work on control chart applications in healthcare is carried out in Surgery, Emergency and Epidemiology departments. Little work is done in other departments like Pulmonary, Radiology, and 
Table 3. Literature survery in Epidemiology department

\begin{tabular}{|c|c|c|c|c|c|}
\hline $\begin{array}{l}\text { Author } \\
\text { and Year }\end{array}$ & Details of work done & $\begin{array}{l}\text { Types of } \\
\text { chart }\end{array}$ & Variables & Type of study & Country \\
\hline Quesenberry [39] & $\begin{array}{l}\text { Recommended the use of control } \\
\text { charts i.e., Q charts to detect } \\
\text { changes in nosocomial infection rates } \\
\text { in hospitals. The ultimate aim of the } \\
\text { article was to aware the readers } \\
\text { about the modern statistical process } \\
\text { control methods. With the help of } \\
\text { these methods, nosocomial infection } \\
\text { surveillance program became more } \\
\text { effective because of time warning of } \\
\text { the onsets of epidemics. }\end{array}$ & Q chart & Infections rate & $\begin{array}{l}\text { Retrospective } \\
\text { study }\end{array}$ & US \\
\hline Gustafson [40] & $\begin{array}{l}\text { The author reduced infection using } \\
\text { risk adjusted quality control chart. } \\
\text { The results showed that unadjusted } \\
\text { control charts (c, p and u charts) } \\
\text { were not effective in healthcare as } \\
\text { these charts with } 3 \text { sigma limits had } \\
\text { sensitivity less than } 50 \% \text { and for } 2 \\
\text { sigma limits had specificity less than } \\
50 \% \text {. On the other hand, risk } \\
\text { adjusted control chart performed } \\
\text { much better based on standardized } \\
\text { infection ratio. The author found } \\
\text { that XMR Chart were most suitable } \\
\text { as having sensitivity and specificity } \\
\text { greater than } 80 \% \text {. So in this way, } \\
\text { these findings suggested specific } \\
\text { techniques and statistics that could } \\
\text { make control charts more suitable } \\
\text { and vtable and valuable for infection } \\
\text { control. }\end{array}$ & $\begin{array}{l}\text { p chart, Run } \\
\text { chart, } \\
\text { XMRchart }\end{array}$ & $\begin{array}{l}\text { Standardized } \\
\text { infection ratio }\end{array}$ & $\begin{array}{l}\text { Retrospective } \\
\text { study }\end{array}$ & US \\
\hline $\begin{array}{l}\text { Hanslik } \\
\text { et al. [41] }\end{array}$ & $\begin{array}{l}\text { The authors performed a pilot study } \\
\text { during } 1998 \text { World Football Cup } \\
\text { with the help of } 553 \text { sentinel general } \\
\text { practitioners. The data related to the } \\
\text { number of persons refereed to } \\
\text { hospital, average number of cases of } \\
\text { environmental, communicable and } \\
\text { social diseases were collected daily } \\
\text { by general practitioners and plotted } \\
\text { on u chart. The parameters selected } \\
\text { for the study remain under control } \\
\text { with the use of control chart. }\end{array}$ & u chart & $\begin{array}{l}\text { Number of } \\
\text { patients }\end{array}$ & $\begin{array}{l}\text { Longitudinal } \\
\text { study }\end{array}$ & France \\
\hline $\begin{array}{l}\text { Arantes } \\
\text { et al. } \\
{[42]}\end{array}$ & $\begin{array}{l}\text { Recommended the use of SPC charts } \\
\text { for the close monitoring of } \\
\text { nosocomial infections (NI) in } \\
\text { hospital. Results showed that mean } \\
\text { NI incidence was } 20 \text { per } 1000 \text { patient }\end{array}$ & $\mathrm{p}$ chart & $\begin{array}{l}\text { Number of } \\
\text { nosocomial } \\
\text { infections per } \\
\text { thousand } \\
\text { patient days }\end{array}$ & $\begin{array}{l}\text { Longitudinal } \\
\text { study }\end{array}$ & Brazil \\
\hline
\end{tabular}
days. The one out of control point was identified in July 2010 with an infection rate 63 per 1000 patient days which showed the period of epidemic. Finally, it can be concluded that use of SPC for controlling infection allowed for identification of uncommon variations in infection rate. This thing was made possible without the need of hypothesis testing and complicated calculations. 
Table 3. (continued).

\begin{tabular}{|c|c|c|c|c|c|}
\hline $\begin{array}{l}\text { Author } \\
\text { and Year }\end{array}$ & Details of work done & $\begin{array}{l}\text { Types of } \\
\text { chart }\end{array}$ & Variables & Type of study & Country \\
\hline $\begin{array}{l}\text { Grant } \\
\text { and Kim [43] }\end{array}$ & $\begin{array}{l}\text { The authors explored the various } \\
\text { ways to measure the important } \\
\text { function of infection control process. } \\
\text { The retrospective study was } \\
\text { conducted for seven years. The chart } \\
\text { utilized were XMR along with } \\
\text { Pearson's correlation coefficient. As a } \\
\text { result of seven years of study, } \\
\text { consultation process became more } \\
\text { efficient. The reason for this increase } \\
\text { in efficiency could be attributed to } \\
\text { increase in number of questions } \\
\text { which lead to decrease in duration to } \\
\text { accomplish closure. }\end{array}$ & XMR chart & $\begin{array}{l}\text { Number and } \\
\text { duration of } \\
\text { infection } \\
\text { control } \\
\text { consultations }\end{array}$ & $\begin{array}{l}\text { Retrospective } \\
\text { study }\end{array}$ & US \\
\hline Limaye et al. [44] & $\begin{array}{l}\text { Identified the utility of control chart } \\
\text { for monitoring infections associated } \\
\text { with hospital and recommendation } \\
\text { on how to use chart for infection } \\
\text { surveillance. They recommended the } \\
\text { use of u chart for infection control as } \\
\text { u chart was simple to construct, easy } \\
\text { to interpret. It could also help to } \\
\text { deal with condition like varying } \\
\text { number of patient days, ventilator } \\
\text { days because this chart took into } \\
\text { account variable sample size. }\end{array}$ & $\begin{array}{l}\text { CUSUM, } \\
\text { g chart, } \\
\text { u chart }\end{array}$ & $\begin{array}{l}\text { Number of } \\
\text { Hospital } \\
\text { associated } \\
\text { infections }\end{array}$ & $\begin{array}{l}\text { Longitudinal } \\
\text { study }\end{array}$ & US \\
\hline Curran et al. [45] & $\begin{array}{l}\text { The authors made use of SPC charts } \\
\text { in order to reduce meticillin resistant } \\
\text { staphylococcus aureus. The authors } \\
\text { divided seventy five wards in twenty } \\
\text { four hospitals into three categories. } \\
\text { First category included ward } \\
\text { receiving SPC chart feedback, second } \\
\text { category included wards with SPC } \\
\text { chart feedback with structured } \\
\text { diagnostic tools and finally third } \\
\text { category included wards which } \\
\text { received neither type of feedback. } \\
\text { The authors found that there was } \\
\text { decrement of } 32.3 \% \text { and } 19.6 \% \text { and } \\
23.1 \text { for ward receiving SPC } \\
\text { feedback, SPC \& diagnostic feedback } \\
\text { and no feedback respectively. } \\
\text { Finally, the authors concluded the } \\
\text { control charts as a valuable tool for } \\
\text { disseminating hospital infection data. }\end{array}$ & p chart & $\begin{array}{l}\text { Percentage of } \\
\text { errors }\end{array}$ & $\begin{array}{l}\text { Retrospective } \\
\text { study }\end{array}$ & UK \\
\hline Harbarth et al. [46] & $\begin{array}{l}\text { Investigated the effect of an early } \\
\text { Methicillin-Resistant Staphylococcus } \\
\text { aureus (MRSA) on the patient's } \\
\text { infection rate. The study was } \\
\text { conducted between July } 2004 \text { and }\end{array}$ & Run chart & $\begin{array}{l}\text { MRSA } \\
\text { infections per } \\
1000 \text { patients } \\
\text { days }\end{array}$ & $\begin{array}{l}\text { Retrospective } \\
\text { Study }\end{array}$ & Switzerland \\
\hline
\end{tabular}
conducted between July 2004 and May 2006 among 21,754 patients. The two MRSA control strategies i.e., standard infection control alone and rapid screening on admission with standard infection control were compared. Finally it was concluded that rapid MRSA admission screening strategy does not reduce surgical site infection with low rates of MRSA infection 
Table 3. (continued).

\begin{tabular}{|c|c|c|c|c|c|}
\hline $\begin{array}{l}\text { Author } \\
\text { and Year }\end{array}$ & Details of work done & $\begin{array}{l}\text { Types of } \\
\text { chart }\end{array}$ & Variables & Type of study & Country \\
\hline Wiemken et al. [47] & $\begin{array}{l}\text { Suggested the development of the } \\
\text { application and demonstrate } \\
\text { application using simulated data for } \\
\text { infection prevention. It was } \\
\text { concluded that process control charts } \\
\text { can easily be developed based on } \\
\text { individual facility needs using freely } \\
\text { available software. They outlined the } \\
\text { importance of implementing an easy } \\
\text { to use and free available software } \\
\text { packages for measuring quality } \\
\text { improvement in healthcare. }\end{array}$ & $\mathrm{p}$ chart & $\begin{array}{l}\text { Hand hygiene } \\
\text { compliant per } \\
100 \\
\text { observations }\end{array}$ & $\begin{array}{l}\text { Retrospective } \\
\text { study }\end{array}$ & US \\
\hline
\end{tabular}

Table 4. Literature survery in Radiology department

\begin{tabular}{|c|c|c|c|c|c|}
\hline $\begin{array}{l}\text { Author and } \\
\text { Year }\end{array}$ & Detail of work done & Types of chart & Variables & Types of study & Country \\
\hline $\begin{array}{l}\text { Waterhouse } \\
\text { et al. [48] }\end{array}$ & $\begin{array}{l}\text { Provided guidance on how to } \\
\text { tackle the situation when your } \\
\text { data are incomplete and non- } \\
\text { normal and provide } \\
\text { recommendations on how to select } \\
\text { a particular control chart for } \\
\text { healthcare sector. The result } \\
\text { showed that MEWMA and } \\
\text { MCUSUM are more effective } \\
\text { compared to the T }{ }^{2} \text { chart as the } \\
\text { MEWMA and MCUSUM are able } \\
\text { to detect small to moderate shifts } \\
\text { very quickly irrespective of } \\
\text { correlated or uncorrelated data. It } \\
\text { can be concluded that whenever } \\
\text { there is need for quick detection of } \\
\text { large shift, } \mathrm{T}^{2} \text { is preferred. }\end{array}$ & $\begin{array}{l}\text { Multivariate } \\
\text { chart (T², } \\
\text { MEWMA, } \\
\text { MCUSUM) }\end{array}$ & $\begin{array}{l}\text { Dose area } \\
\text { product, } \\
\text { fluoroscopy time } \\
\text { and Number of } \\
\text { digital images }\end{array}$ & Longitudinal & \\
\hline Study & Australia & & & & \\
\hline $\begin{array}{l}\text { Sanghangthum } \\
\text { et al. [49] }\end{array}$ & $\begin{array}{l}\text { Established the control limits for } \\
\text { percentage gamma pass of patient } \\
\text { specific intensity modulated } \\
\text { radiotherapy (IMRT) and } \\
\text { volumetric modulated arc therapy } \\
\text { (VMAT) quality assurance (QA). } \\
\text { The process capability index was } \\
\text { used to evaluate the efficiency of } \\
\text { process. The average percentage } \\
\text { gamma pass was calculated to be } \\
93.7 \% \pm 3.7 \% \text { for IMRT and } \\
96.7 \% \pm 2.2 \% \text { for VMAT. The } \\
\text { process capability index values for } \\
\text { IMRT QA and VMAT QA was } \\
1.60 \text { and } 1.99 \text { respectively. It was } \\
\text { found that there is lesser } \\
\text { systematic errors in VMAT QA } \\
\text { than IMRT QA because there was } \\
\text { more complicated setup in case of } \\
\text { IMRT QA. }\end{array}$ & $\mathrm{X}$ bar chart & $\begin{array}{l}\text { Percentage } \\
\text { gamma passes }\end{array}$ & $\begin{array}{l}\text { Retrospective } \\
\text { Study }\end{array}$ & Thailand \\
\hline
\end{tabular}


Table 4. (continued).

\begin{tabular}{|c|c|c|c|c|c|}
\hline $\begin{array}{l}\text { Author and } \\
\text { Year }\end{array}$ & Detail of work done & Types of chart & Variables & Types of study & Country \\
\hline $\begin{array}{l}\text { Mezzenga et al. } \\
{[50]}\end{array}$ & $\begin{array}{l}\text { Examined the static and dynamic } \\
\text { output of helical tomo therapy } \\
\text { treatment system using SPC. The } \\
\text { binding of acceptable range of } \\
\text { daily output checks was given } \\
\text { importance and recommendations } \\
\text { were given for detailed } \\
\text { investigation of daily output } \\
\text { checks for Helical Tomo Therapy } \\
\text { treatment system. }\end{array}$ & $\begin{array}{l}\text { X bar chart, } \\
\text { Moving range } \\
\text { chart, EWMA }\end{array}$ & $\begin{array}{l}\text { Static and } \\
\text { dynamic output }\end{array}$ & $\begin{array}{l}\text { Retrospective } \\
\text { Study }\end{array}$ & Italy \\
\hline $\begin{array}{l}\text { Fuangrod et al. } \\
{[51]}\end{array}$ & $\begin{array}{l}\text { Provided recommendation for } \\
\text { quality evaluation of individual } \\
\text { patient and identify the gap for } \\
\text { continuous quality improvement. } \\
\text { The process capability indices } \\
\text { were evaluated for rectum and } \\
\text { pelvis cancer treatments and } \\
\text { found to less than one. The } \\
\text { control limits were identified as } \\
62.5 \text { and } 70.0 \% \text { of the } \chi \text { pass-rate } \\
\text { for intensity-modulated } \\
\text { radiotherapy and deliveries } \\
\text { respectively. }\end{array}$ & $\begin{array}{l}\text { Moving range } \\
\text { chart }\end{array}$ & $\chi$ pass-rate & Longitudinal & \\
\hline Study & Australia & & & & \\
\hline Lee et al. [52] & $\begin{array}{l}\text { Applied the SPC charts for head, } \\
\text { neck, breast and prostate cases of } \\
\text { intensity modulated radiation } \\
\text { therapy (IMRT) or volumetric arc } \\
\text { radiation therapy (VMAT). The } \\
\text { number of patients data utilized } \\
\text { for head, neck, prostate and breast } \\
\text { were } 73,68,49 \text { and } 152 \\
\text { respectively. Finally it was } \\
\text { concluded that VMAT quality } \\
\text { assurance has better process } \\
\text { capability than IMRT. The } \\
\text { authors suggested paying more } \\
\text { attention for planning and quality } \\
\text { assurance before breast } \\
\text { radiotherapy treatment. }\end{array}$ & XMR chart & $\begin{array}{l}\text { Number of } \\
\text { patient }\end{array}$ & $\begin{array}{l}\text { Retrospective } \\
\text { Study }\end{array}$ & Korea \\
\hline
\end{tabular}

Cardiology etc. Another thing should be noted that the control charts applications in healthcare at departmental level are very limited i.e. out of 142 articles; only 40 have been selected. These data also show great opportunities for control chart to be applied in other departments like Pathology, Pharmacy, Inpatient, Outpatient departments etc. Similarly from Figure 6, it is clear that most of work on control chart is carried out in developed countries like US, UK and Australia. That shows the huge gape of deploying control charts in healthcare at departmental level in different countries. The countries like India, China and Russia etc. have great opportunity to apply control charts in healthcare sector.
Figure 7 shows the types of control charts used in healthcare in the included studies. It is clear from Figure 7 that $\mathrm{p}$ chart, $\mathrm{X}$ bar chart and run chart are the mostly implemented in the healthcare applications. That shows the great applicability of these charts in healthcare. The CUSUM, EWMA and XMR charts are also used frequently. There is very little use of c chart, $\mathrm{g}$ chart, and $u$ charts in healthcare sector. The use of multivariate chart is also very less but its use should be increased in the future. The reason for less use of multivariate chart may be due to complications in the design of chart and it is also very difficult to identify which factor contributes to the assignable causes of variations. 
Table 5. Literature survery in Pulmonary department

\begin{tabular}{|c|c|c|c|c|c|}
\hline $\begin{array}{l}\text { Author and } \\
\text { Year }\end{array}$ & Details of work done & Types of chart & Variables & Types of study & Country \\
\hline $\begin{array}{l}\text { Correia et al. } \\
{[53]}\end{array}$ & $\begin{array}{l}\text { Provided the timely treatment to } \\
\text { chronic obstructive disease } \\
\text { patient by monitoring and } \\
\text { controlling of complications. It } \\
\text { was concluded that when the } \\
\text { objective was to find out changes } \\
\text { in mean only then one sided } \\
\text { control charts were more suitable. } \\
\text { So in order to detect previously } \\
\text { unidentified out of control points, } \\
\text { one side multi and univariate } \\
\text { charts were constructed. It was } \\
\text { recommended that one sided } \\
\text { control charts were valuable tools } \\
\text { for monitoring healthcare and in } \\
\text { this way contributing to medical } \\
\text { decision making. }\end{array}$ & $\begin{array}{l}\text { Multivariate } \\
\text { chart }\end{array}$ & $\begin{array}{l}\text { Body mass } \\
\text { index, } \mathrm{PaO}_{2} \text {, } \\
\mathrm{PaCo}_{2}\end{array}$ & Longitudinal & \\
\hline Study & Portugal & & & & \\
\hline $\begin{array}{l}\text { Alsadat et al. } \\
{[54]}\end{array}$ & $\begin{array}{l}\text { Reduced ventilator associated } \\
\text { pneumonia (VAP) rate for all } \\
\text { mechanically ventilated patients. } \\
\text { It was found that VAP bundle } \\
\text { compliance rate was gradually } \\
\text { increased in all the hospitals. No } \\
\text { data was available for hospital } 4 \\
\text { as the VAP bundle was not } \\
\text { applied in it. Only hospital } 3 \text { had } \\
\text { achieved a target of } 95 \% \text {. The } \\
\text { suggested multidimensional } \\
\text { strategy from top management is } \\
\text { needed in order to prevent VAP } \\
\text { rate which included interventions } \\
\text { for infection control, process } \\
\text { monitoring and outcome } \\
\text { surveillance. }\end{array}$ & Run Chart & $\mathrm{VAP}$ rate & Longitudinal & \\
\hline Study & Saudi Arabia & & & & \\
\hline
\end{tabular}

The included studies are divided into two categories on the basis of process of data collection. If the data is taken directly from the hospital staff, the study is called retrospective study. On the other hand, if close watch is done on the process in order to take the data, the study comes under the category of longitudinal study. Out of 37 included studies, 25 are retrospective studies and rest are longitudinal study as shown in Figure 8. Researchers found that, longitudinal study is better than retrospective study because it gives the idea about current situation of the process. So in future, number of longitudinal studies should be increased.

It is found in the literature survey that the mostly used variables for the construction of control charts are mortality rate, number of complications in particular number of cases, Rate of surgical site infections, length of stay, door to needle time etc. Since healthcare involves lot of complications, so selection of variable is very important.
Figure 9 shows the distribution of number of studies in different departments across the timeline. The matrix plot is two dimensional. Firstly, it tells about number of studies in different departments and secondly, it shows the timing of studies. It is evident from Figure 9 that, control charts in Emergency, Surgery and Epidemiology departments are used at regular intervals. Literature survey shows that Emergency department is always associated with longer waiting time and overcrowded room. So there is always space for the improvement in Emergency department. On the other hand, Surgery and Epidemiology department is overburdened with errors and inefficiencies. These are the possible reasons for regular use of control charts in these departments. The control charts are slowly expanding to Pulmonary, Cardiology, Radiology and Pharmactuel as it is depicted from Figure 9. So there is lot of scope of implementing control charts in these departments in future. 
Table 6. Literature survery in Cardiology department

\begin{tabular}{|c|c|c|c|c|c|}
\hline $\begin{array}{l}\text { Author and } \\
\text { Year }\end{array}$ & Details of work done & Types of chart & Variables & Types of study & Country \\
\hline $\begin{array}{l}\text { Bonetti et al. } \\
\text { [55] }\end{array}$ & $\begin{array}{l}\text { The authors used SPC to reduce the } \\
\text { door to needle time for patients of } \\
\text { acute myocardial infraction. In the } \\
\text { starting, the door to needle time for } \\
\text { patients was found to be } 57 \text { minutes } \\
\text { on average basis. After finding and } \\
\text { eliminating the root causes of the } \\
\text { problem, time was reduced to } 24 \\
\text { minutes. It was concluded the } \\
\text { formal process analysis technique is } \\
\text { suitable to improve the processes in } \\
\text { intensive care unit. }\end{array}$ & Run Chart & $\begin{array}{l}\text { Door to needle } \\
\text { time }\end{array}$ & $\begin{array}{l}\text { Longitudinal } \\
\text { study }\end{array}$ & Switzerland \\
\hline $\begin{array}{l}\text { Coory et al. } \\
\text { [56] }\end{array}$ & $\begin{array}{l}\text { Monitored the quality of hospital } \\
\text { care by using administrative data. } \\
\text { CUSUM charts were utilized and no } \\
\text { outliers were found on cross- } \\
\text { sectional funnel plot, using three } \\
\text { sigma limits for either of two years. } \\
\text { It was concluded that control charts } \\
\text { were valuable tools in the sense that } \\
\text { these provide an early detection of } \\
\text { good and bad result. So that } \\
\text { hospital could trace out the areas } \\
\text { which need more examining and } \\
\text { monitoring. }\end{array}$ & CUSUM & Mortality rate & $\begin{array}{l}\text { Retrospective } \\
\text { study }\end{array}$ & Australia \\
\hline
\end{tabular}

Table 7. Literature survery in Administration department

\begin{tabular}{|c|c|c|c|c|c|}
\hline $\begin{array}{l}\text { Author and } \\
\text { Year }\end{array}$ & Details of work done & $\begin{array}{l}\text { Types of } \\
\text { chart }\end{array}$ & Variables & Types of study & Country \\
\hline $\begin{array}{l}\text { Gabbay and } \\
\text { Bukchin [57] }\end{array}$ & $\begin{array}{l}\text { Monitored whether the numbers of } \\
\text { staff nurses meets the daily workload } \\
\text { requirements. The results showed } \\
\text { that } 42 \% \text { of the total days fell within } \\
\text { the acceptable control limits and on } \\
\text { the other hand, } 71 \% \text { fell within } \\
\text { tolerable control limits. The authors } \\
\text { found that only } 33 \% \text { of the wards } \\
\text { showed acceptable nurse workload. }\end{array}$ & Run Chart & $\begin{array}{l}\text { Nurse } \\
\text { attendance and } \\
\text { ward workload }\end{array}$ & $\begin{array}{l}\text { Retrospective } \\
\text { study }\end{array}$ & Israel \\
\hline Canel et al. [58] & $\begin{array}{l}\text { Analysed and reduced the time for } \\
\text { making medical record. The hospital } \\
\text { improved the efficiency and } \\
\text { effectiveness of assemble record } \\
\text { process as there was significant } \\
\text { reduction in the medical records } \\
\text { assembly time. The authors } \\
\text { implemented a new procedure, as a } \\
\text { result of which medical record stayed } \\
\text { time reduced from } 9 \text { to } 7.6 \text { days. }\end{array}$ & c chart & $\begin{array}{l}\text { Total } \\
\text { Completion } \\
\text { time for } \\
\text { assembly record }\end{array}$ & $\begin{array}{l}\text { Longitudinal } \\
\text { Study }\end{array}$ & US \\
\hline Chien et al. [59] & $\begin{array}{l}\text { Examined the quality performance of } \\
\text { hospital using intraclass correlation } \\
\text { coefficient. In order to annually assess }\end{array}$ & $\begin{array}{l}\text { Regression } \\
\text { chart, XMR } \\
\text { chart }\end{array}$ & $\begin{array}{l}\text { Intraclass } \\
\text { correlation } \\
\text { coefficient }\end{array}$ & $\begin{array}{l}\text { Retrospective } \\
\text { study }\end{array}$ & Taiwan \\
\hline
\end{tabular}


Table 7. (continued).

\begin{tabular}{|c|c|c|c|c|c|}
\hline $\begin{array}{l}\text { Author and } \\
\text { Year }\end{array}$ & Details of work done & $\begin{array}{l}\text { Types of } \\
\text { chart }\end{array}$ & Variables & Types of study & Country \\
\hline & $\begin{array}{l}\text { across hospitals, the authors } \\
\text { developed the intraclass correlation } \\
\text { coefficient. The authors found that all } \\
\text { hospitals groups presented a slowly } \\
\text { well control supply of services that } \\
\text { decrease from } 0.772 \text { to } 0.415 \text {. Finally, } \\
\text { authors preferred intraclass } \\
\text { correlation coefficient to annually } \\
\text { assess a country's year based } \\
\text { convergent power. }\end{array}$ & & & & \\
\hline
\end{tabular}

Table 8. Literature survery in Pharmactuel Department.

\begin{tabular}{|c|c|c|c|c|c|}
\hline $\begin{array}{l}\text { Author and } \\
\text { Year }\end{array}$ & Details of work done & Type of chart & Variables & Type of study & Country \\
\hline $\begin{array}{l}\text { Spiridonica } \\
{[60]}\end{array}$ & $\begin{array}{l}\text { The author analysed the process of } \\
\text { ampicillin bottles, of } 1000 \mathrm{mg}, 500 \mathrm{mg} \text { and } \\
250 \mathrm{mg} \text {. It was concluded that this } \\
\text { application is very useful and easy to apply } \\
\text { for all specialists working in industrial } \\
\text { quality assurance. }\end{array}$ & $\bar{X}$ Chart & $\begin{array}{l}\text { Weight of } \\
\text { bottles }\end{array}$ & $\begin{array}{l}\text { Retrospective } \\
\text { study }\end{array}$ & Romania \\
\hline $\begin{array}{l}\text { Prajapati } \\
\text { [61] }\end{array}$ & $\begin{array}{l}\text { The author countered the autocorrelation } \\
\text { by presenting the new } \bar{X} \text { chart based on } \\
\text { Chi-squares theory. The readings were } \\
\text { taken for the quantity of syrup and level of } \\
\text { correlation was found and compared with } \\
\text { new } \bar{X} \text { chart for sample size of four. The } \\
\text { level of correlation was found to be } 0.50 \\
\text { among the industry data. Finally it was } \\
\text { concluded that wherever there is } \\
\text { autocorrelation in the industries, it is more } \\
\text { economical to use new } \bar{X} \text { chart than } \\
\text { traditional X bar chart for sample size of } \\
\text { four. }\end{array}$ & $\bar{X}$ Chart & $\begin{array}{l}\text { Quantity of } \\
\text { syrup }\end{array}$ & $\begin{array}{l}\text { Retrospective } \\
\text { study }\end{array}$ & India \\
\hline $\begin{array}{l}\text { Prajapati } \\
\text { and Singh } \\
{[62]}\end{array}$ & $\begin{array}{l}\text { The level of correlation for the weights of } \\
\text { tablets was computed in pharmaceutical } \\
\text { industry by using } \bar{X} \text { chart. The design of } \\
\text { chart was modified based upon the Chi- } \\
\text { square theory. The parameter selected in } \\
\text { order to evaluate the performance of chart } \\
\text { is the average run length (ARL). It was } \\
\text { concluded that modified } \bar{X} \text { chart have } \\
\text { better performance than traditional } \bar{X} \\
\text { chart. }\end{array}$ & $\bar{X}$ Chart & $\begin{array}{l}\text { Weight of } \\
\text { tablets }\end{array}$ & $\begin{array}{l}\text { Retrospective } \\
\text { study }\end{array}$ & India \\
\hline
\end{tabular}

Similarly, it is depicted from Figure 10 that only US shows regular interval use of control chart in healthcare. In case of UK, Australia and France, there is also a better distribution of studies throughout the years but not as uniform as in United States of America. Other countries like Portugal, Nigeria, Israel, Saudi Arabia, Italy, India and Germany start implementing control chart in healthcare from 2009 onwards and there is great opportunity for regular interval use in the future. Figure 11 shows the distribution for number of studies employing different types of charts across the time line. It is clear from Figure 11 that $\mathrm{p}$ chart, $\mathrm{X}$ bar chart and run charts show regular interval use starting from 1996 to till 2017. That shows the great applicability of these charts in healthcare. CUSUM and EWMA charts come into 


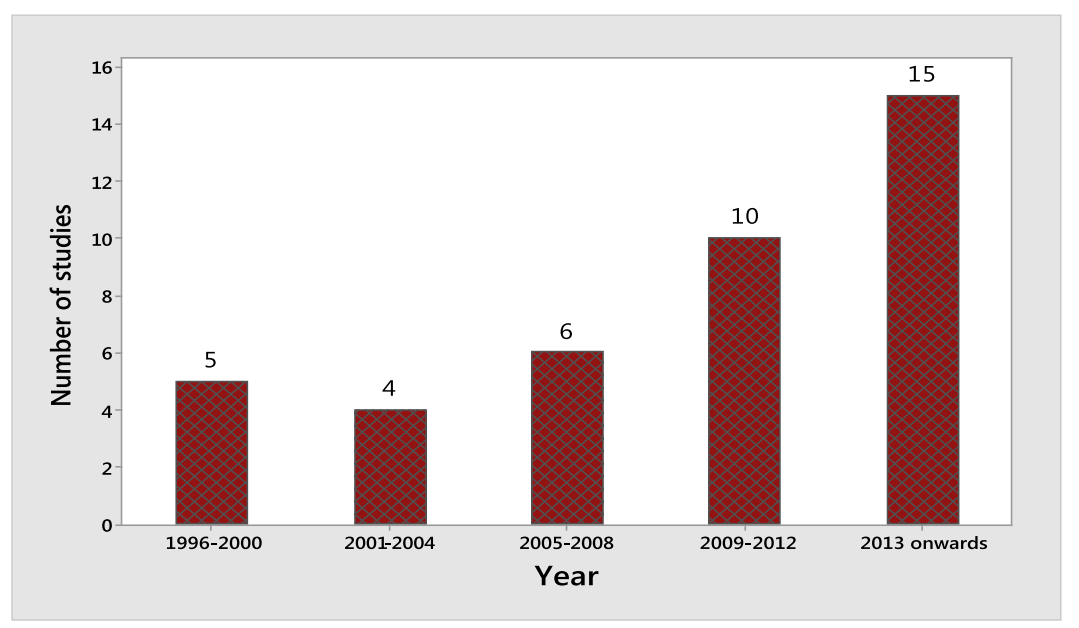

Fig. 4. Number of studies performed in various years.

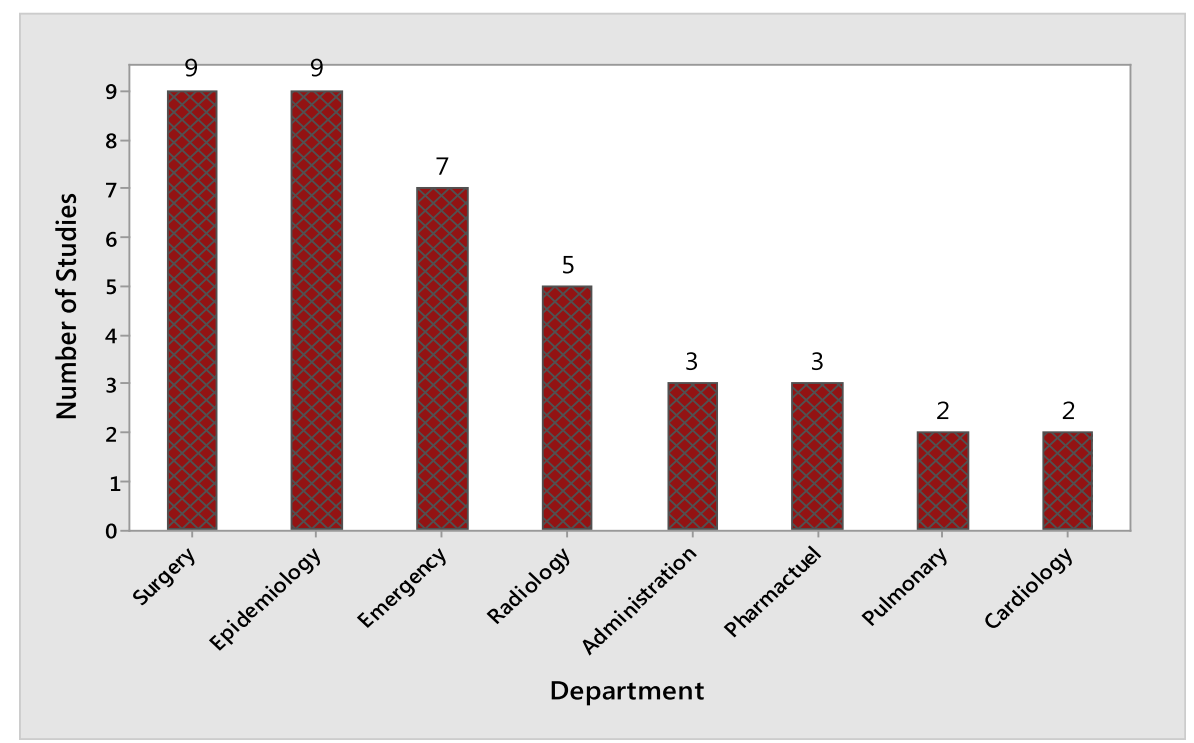

Fig. 5. Number of studies performed in various departments of hospitals.

picture after 2008 and show continuous use after that. Multivariate charts are rarely used in healthcare. There is great possibility in future to come up with.

One thing should be noted that during construction of control chart, the performance of individuals in hospitals is direct under observation. So, some chances of errors in implementing the control charts are possible. This is called Hawthorne effect. The Hawthorne effect, also known as the observation bias, refers to alteration of an individual's behaviour as a result of being observed and therefore improvements in productivity may be as a consequence of the observation rather than the efficacy of a specific intervention. So Hawthorne effect or observation bias needs to be minimised during the observations.

\section{Limitations}

There are various benefits of applying SPC in healthcare like its simplicity, improvement of process, identification of areas of improvement, investigating the impact of changes to the process, prediction of the future process performance etc. But there are some inherent limitations. The difficulty in obtaining the baseline data for process performance is one of the major challenges while applying control charts in healthcare sector. The plotting of performance data do not automatically lead to improvement of the process. It needs the strong top management commitment in order to make the required changes. The behaviour of the employees during collection of data for control chart may be biased.

Another limitation is that statistical control cannot equate with clinical control. The chart under statistical control tells only the absence of special cause(s) of variation. Even if the chart shows the process under statistical control, it does not give the guaranty for risk of other kinds of infections to the patients. Similarly; the conditions of patients admitted to the hospitals vary according to severity of their illness. So this also limits the appropriateness of combining data into one control chart. 


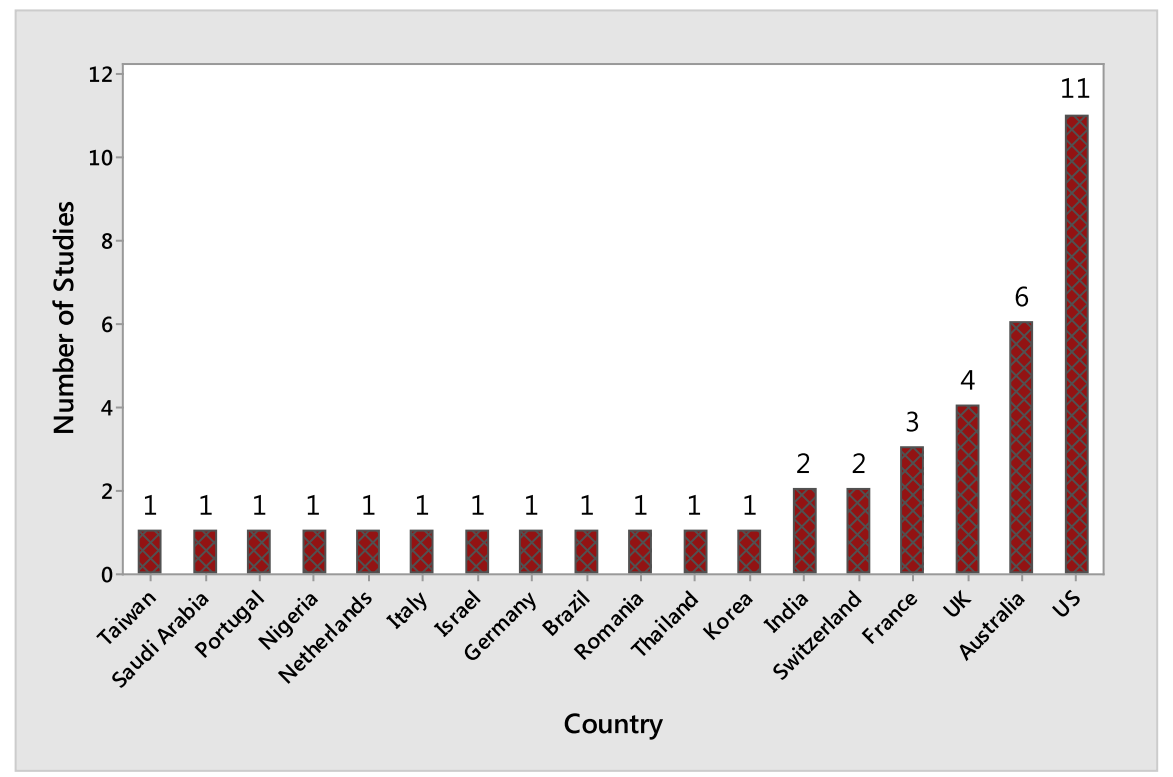

Fig. 6. Number of studies included from different countries.

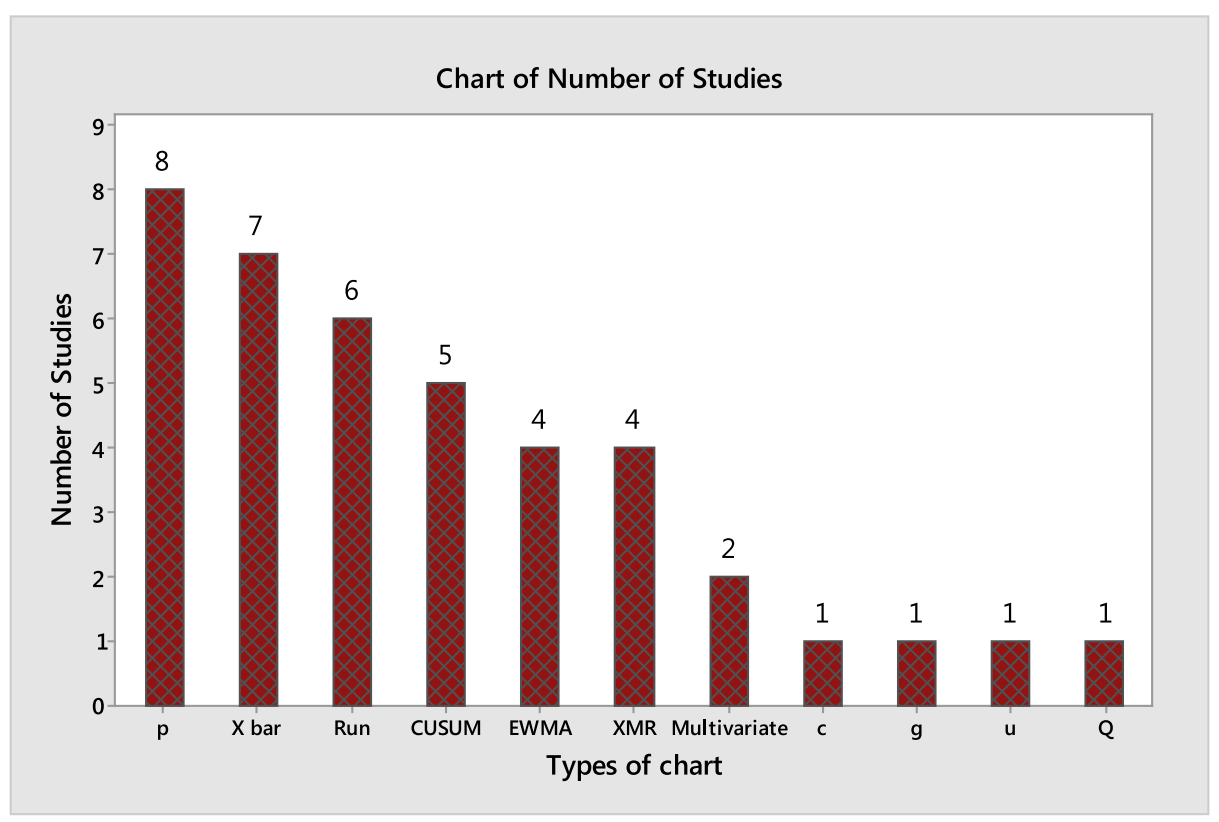

Fig. 7. Number of studies employing different types of charts.

\section{Managerial and academic implications}

The finding of this review paper is valuable to the researchers and practitioners; who seek to improve the quality of healthcare by applying control charts. The paper provides the departments which are responsible for maximum studies and in addition also provides the gaps for further research in departments; which accounts for minimum studies. This review also provides the information to the researchers about the control charts which have rarely been used in healthcare.
The control charts in healthcare industry provides the necessary information to the management regarding process capability. The failure of control charts implementation is generally due to lack of management support, lack of training and other social and human factors. So there is strong need of top management commitment before starting SPC project. The top management should incorporate the quality initiatives in their business strategy in order to improve the healthcare quality. 


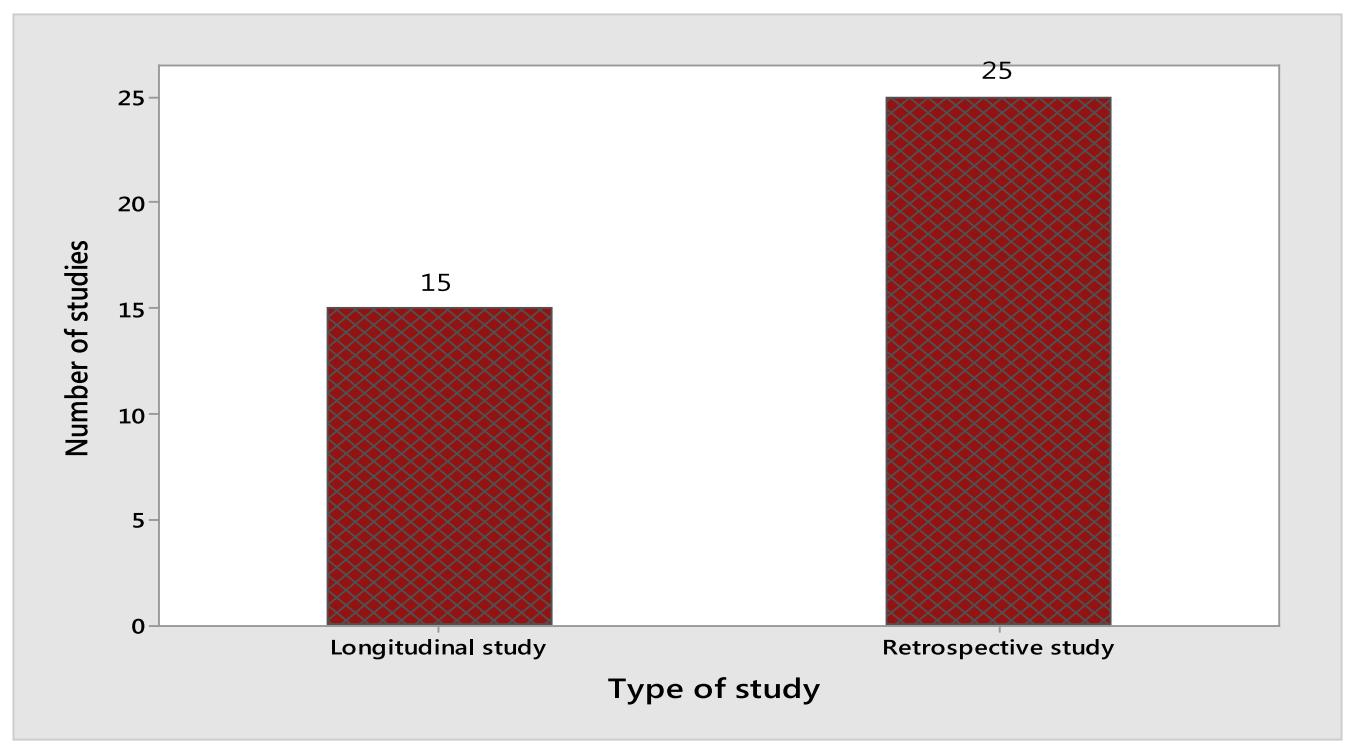

Fig. 8. Bar chart for longitudinal and retrospectives studies.

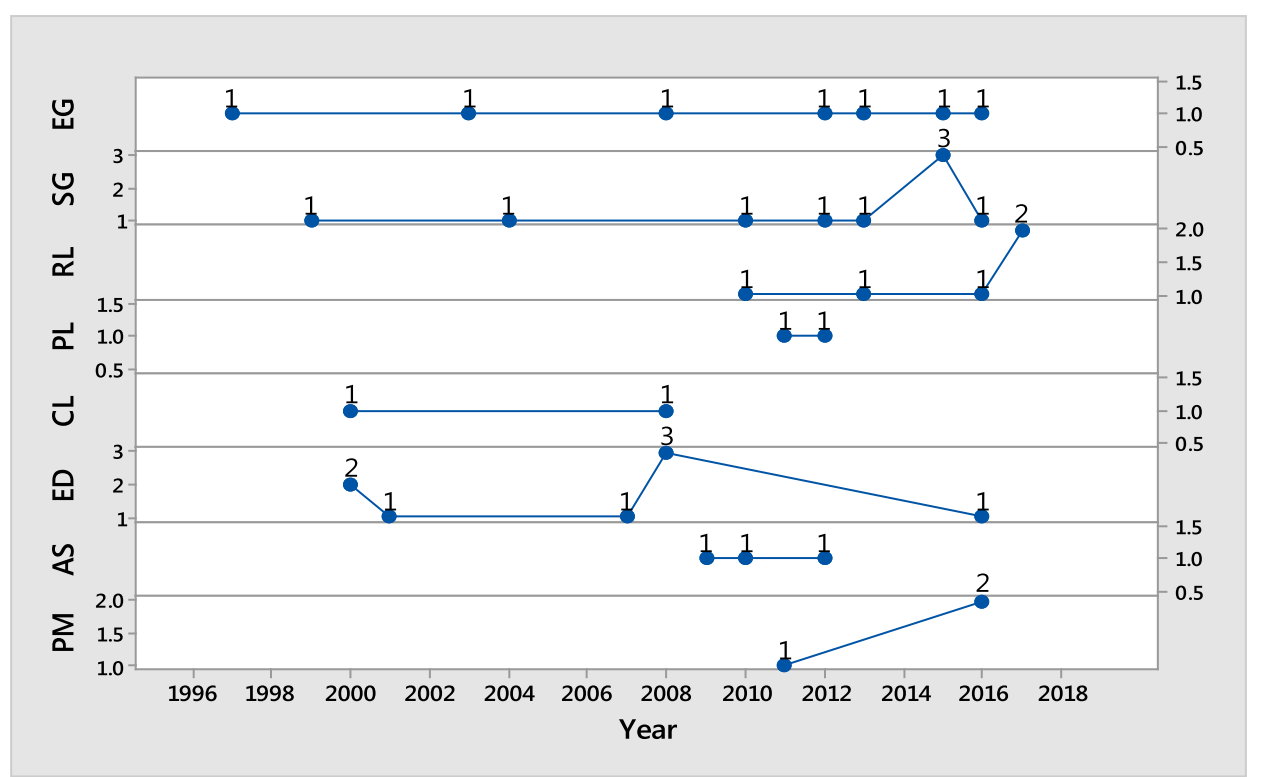

Fig. 9. Year wise matrix plot for number of studies in various departments $(E G=$ Emergency, $S G=S u r g e r y, R L=R a d i o l o g y$, $\mathrm{PL}=$ Pulmonary, $\mathrm{CL}=$ Cardiology, $\mathrm{ED}=$ Epidemiology, $\mathrm{AS}=$ Administration, $\mathrm{PM}=$ Pharmactuel $)$.

\section{Conclusions}

Healthcare is always overburdened with errors, infections, pre and post-operative complications, longer waiting time, length of stay, complications etc. As there is more involvement of human, the chances of errors are also more. SPC i.e., control charts can help in determining the source of errors by identifying the special causes of variations in healthcare sector.

Literature survey shows that most of work on control charts applications in healthcare is carried out in Surgery, Emergency and Epidemiology departments. US, UK and
Australia are responsible for maximum amount of work. Matrix plots show that there is regular interval use of control chart in Emergency, Surgery and Epidemiology department and only US shows regular interval use of control chart in healthcare. This shows the huge gap of deploying control chart in other departments and others countries as well. It is also found that $\mathrm{p}$ chart, $\mathrm{X}$ bar chart and run chart have been used regularly across the time line. That shows the great applicability of these charts in healthcare. CUSUM and EWMA charts are also being used since 2008. Multivariate charts are rarely used in healthcare. 


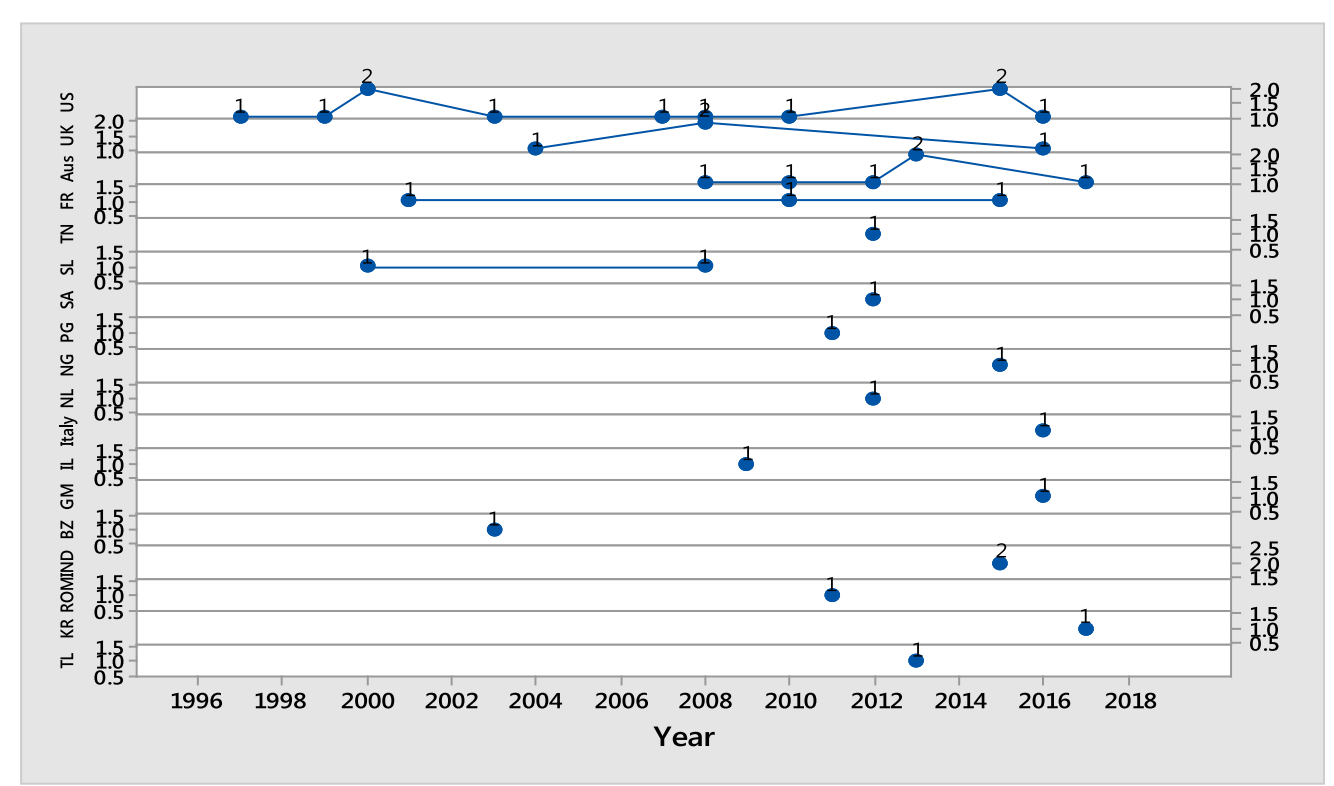

Fig. 10. Year wise matrix plot for number of studies in various Countries (US=United States, UK=United Kingdom, Aus $=$ Australia, $\mathrm{FR}=$ France, $\mathrm{TN}=$ Taiwan, $\mathrm{SL}=$ Switzerland, $\mathrm{SA}=$ Saudi Arabia, $\mathrm{PG}=$ Portugal, $\mathrm{NG}=\mathrm{Nigeria}, \mathrm{NL}=\mathrm{Nether}-$ lands, $\mathrm{IL}=$ Israel, GM $=$ Germany, BZ = Brazil, Ind $=$ India, Rom $=$ Romania, $\mathrm{KR}=$ Korea, $\mathrm{TL}=\mathrm{Thailand})$.

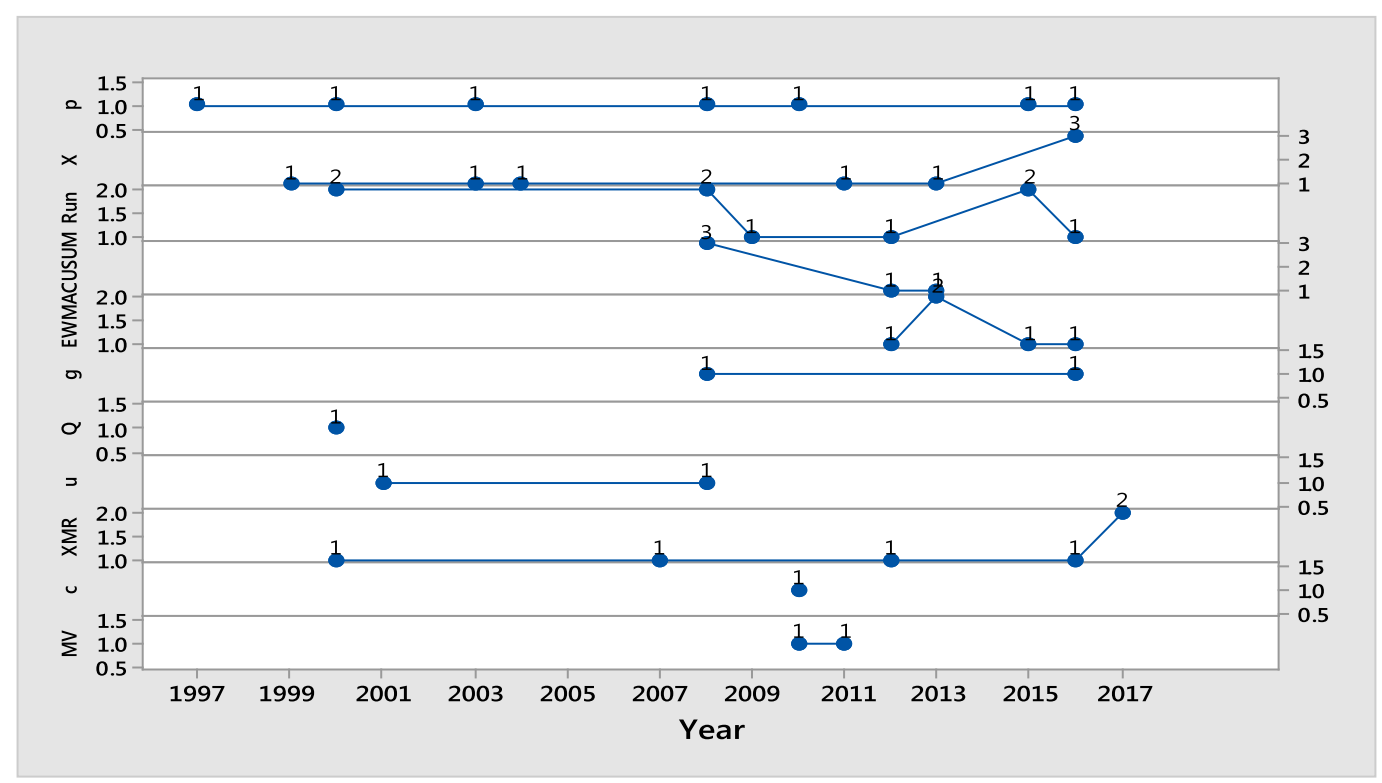

Fig. 11. Year wise matrix plot for number of studies employing different types of charts (MV= Multivariate chart).

SPC is multifaceted tool which enable the staff and physicians in healthcare to continuously monitor and improve the patients' health. A strong evaluation of control chart is required to apply control chart in other departments like Pathology, Pharmacy, Inpatient, Outpatient etc. The limitation of this study is that numbers of included studies are less. So in future, statistical analysis can be performed on larger scale in order to generalize the results.

\section{References}

1. I. Lazarus, C. Neely, Six sigma raising the bar, Manag. Healthc Exec. 13, 31-33 (2003)
2. Department of Health, Organisation with a Memory: Report of an Expert Group on Learning from Adverse Events in the NHS chaired by the Chief Medical Officer, The Stationery Office, London (2001)

3. F. Milligan, K. Robinson, Limiting Harm in Future Health Care - the Role of Nursing: A Nursing Perspective (Blackwell Publishing, Oxford, 2003), pp. 255-273

4. J. Arthur, Lean six sigma for hospitals, Improving patient safety, patient flow and the bottom line, Second edition (McGraw-Hill Education, 2016) pp. xvii-xviii

5. L.J. Finison, K.S. Finison, C.M. Bliersbacl, Use of control chart to improve healthcare quality, J. Healthc. Qual. 15, 923 (1993) 
6. L.J. Finison, K.S. Finison, Applying control chart for quality improvement, J. Healthc. Qual. 18, 32-41 (1996)

7. J.C. Benneyan, Statistical quality control methods in infection control and hospital epidemiology, part II: chart use, statistical properties, and research issues, Infect. Control Hosp. Epidemiol. 19, 265-282 (1998)

8. B.L. Maccarthy, T. Wasusri, A review of nonstandard application of statistical process control (SPC) charts, Int. J. Qual. Reliab. Manag. 19, 295-320 (2002)

9. F. Clemente, M. Papi, L. Pontecorvi, A. Menichetti, Evaluation of indices for the measurement of quality in health systems, Int. J. Metrol. Qual. Eng. 7, 1-14 (2016)

10. X. Ning, Y. Shang, F. Tsung, Statistical process control for service processes: A review, 6th International conference on Service Systems and Service Management, pp. 927-931 (2009)

11. F.C. Kaminsky, J. Maleyeff, D.L. Mullins, Using SPC to analyse measurements in healthcare orgainsations, J. Healthc. Risk Manag. 18, 36-46 (1998)

12. S.G. Amin, Control chart 101: A guide to healthcare applications, Qual. Manag. Healthc. 9, 1-27 (2001)

13. J. Thor, J. Lundberg, J. Ask, J. Olsson, C. Carli, K.P. Harenstam, M. Brommels, Application of statistical process control in healthcare improvement: systematic review, Qual Saf Healthc. 16, 387-399 (2007)

14. A. Koetsier, S.N.V. Veer, K.J. Jager, N. Peek, N.F. De Keizer, Control chart for healthcare quality improvement: A systematic review on adherence to methodological criteria, Methods Inf. Med. 51, 189-198 (2012)

15. D. Laney, Improved control charts for attributes, Qual. Eng. 14, 531-537 (2002)

16. M.A. Mohammed, D. Laney, Overdispersion in health care performance data: Laney's approach, Qual Saf. Healthc. 15, 383-384 (2006)

17. D.R. Prajapati, Cost comparisons of modified chart for autocorrelated observations, Int. J. Metrol. Qual. Eng. 7, 102-p1-102-p9 (2016a)

18. W.H. Woodall, The use of control chart in healthcare and public health surveillance, J. Qual. Technol. 38, 89-104 (2006)

19. M. Pillet, A. Boukar, E. Pairel, B. Rizzon, N. Boudaoud, Z. Cherfi, Multivariate SPC for total inertial tolerancing, Int. J. Metrol. Qual Eng. 4, 169-175 (2013)

20. M.E. Seddon, M.N Marshall, S.M. Campbell, M.O. Roland, Systematic review of studies of quality of clinical care in general practice in the UK, Australia and New Zealand, Qual. Healthc. 10, 152-158 (2001)

21. J.A. Sellick, The use of statistical process control charts in hospital epidemiology, Infect. Control Hosp. Epidemiol. 14, 649-656 (1993)

22. A.P. Morton, Whitby, M., M.L. Mclaws, A. Dobson, S. Mcelwain, D. Looke, J. Stackelroth, A. Sartor, The application of statistical process control charts to the detection and monitoring of hospital acquired infections, J. Qual. Clin. Prac. 21, 112-117 (2001)

23. F.C. Kaminsky, J. Maleyeff, S. Providence, E. Purinton, M. Waryasz, Using SPC to analyse quality indicators in a healthcare organization, J. Healthcare Risk Manag. 17, 1422 (1997)

24. C.D. Callahan, D.L. Griffen, Advanced statistics: applying statistical process control techniques to Emergency medicines: A primer for providers, Acad. Emerg. Med. 10, 883$890(2003)$
25. S. Gilligan, M. Walters, Quality improvement in hospital flow may lead to a reduction in mortality, Clin. Gov.: Int. J. 13, 26-34 (2008)

26. L. Minne, S. Eslami, N.D. Keizer, E.D. Jonge, S.E.D. Rooij, A. Abu-Hanna, Statistical process control for validating a classification tree model for predicting mortality-A novel approach towards temporal validation, J. Biomed. Inf. 45, 37-44 (2012)

27. J.L. Moran, P. J. Solomon, ANZICS, Statistical process control of mortality series in the Australian and New Zealand intensive care society (ANZICS) adult patient database: implications of data generating process, BMC Med. Res. Methodol. 13, 66-78 (2013)

28. F. Harrou, Y. Sun, F. Kadri, S. Chaabane, S. Tahon, Early detection of abnormal patient arrivals at hospital Emergency department, 6th International Conference on Industrial Engineering and Systems Management (2015)

29. C. Pagel, P. Ramnarayan, S. Ray, M.J. Peters, Development and implementation of a real time statistical control method to identify the start and end of winter surge in demand for paediatric intensive care, Eur. J. Oper. Res., 264, 847-858 (2016)

30. J.M. Levett, R.G. Carey, Measuring for improvement: From Toyota to thoracic Surgery, Ann. Thorac. Surg. 68, 353-358 (1999)

31. M.A. Mohammed, Using statistical process control to improve the quality of healthcare, Qual. Saf. Healthc. 13, 243-245 (2004)

32. A. Duclos, N. Voirin, The p control chart: a tool for care improvement, Int. J. Qual. Healthc., 22, 402-407 (2010)

33. M.A. Jones, S.H. Steiner, Assessing the effect of estimation error on risk adjusted CUSUM chart performance, Int. J. Qual Healthc. 24, 176-181 (2012)

34. I.R. Smith, M.A. Gardner, B. Garlick, R.D. Brighouse, J. Cameron, P.S. Lavercombe, K. Mengersen, K.A. Foster, J.T. Rivers, Performance monitoring in cardiac surgery: application of statistical process control to a single site data, Heart Lung Circ. 22, 634-641 (2013)

35. D.S. Keller, J.J Stulberg, J.K. Lawrence, H. Samia, C.P. Delaney, Initiating statistical process control to improve the quality outcomes in colorectal Surgery, Surg. Endosc. 29, 3559-3564 (2015)

36. P.E. Oguntunde, O.A. Odetunmibi, O.A. Oluwadare, Comparative study of the use of statistical process control in monitoring healthcare delivery, Int. J. Innov. Sci. Res. 14, 154-158 (2015)

37. W.H. Woodall, S.L. Fogel, S.H. Steiner, The monitoring and improvement of surgical outcome quality, J. Qual. Technol. 47, 383-400 (2015)

38. H. Schrem, V. Schneider, M. Kurok, A. Goldis, M. Dreier, A. Kaltenborn, W. Gwinner, M. Barthold, J. Liebeneiner, M. Winny J. Klempnauer, M. Kleine, Independent pre-transplant recipient cancer risk factors after kidney transplantation and the utility of $\mathrm{G}$ chart analysis for clinical process control, Plos One 11, 1-17 (2016)

39. C.P. Quesenberry, Statistical process control geometric Q chart for nosocomial infection surveillance, Am. J. Infect. Control 28, 314-320 (2000)

40. T.L. Gustafson, Practical risk adjusted quality control charts for infection control, Am. J. Infect. Control, 28, 406-414 (2000)

41. N. Hanslik, P.Y. Boelle, A. Flahault, The control chart: Epidemiological tool for public health monitoring, Public Health 115, 277-281 (2001) 
42. A. Arantes, E.D.S. Carvalho, E.A.S. Medeiros, C.K. Farhat, O.C. Mantese, Use of statistical process control in the epidemiological surveillance of nosocomial infections, Rev. Saúde Pública 37, 768-774 (2003)

43. P.S. Grant, A.T. Kim, Infection control consultation in a 150 bed acute care hospital: Making this unobserved and unmeasured critical job function visible, Am. J. Infect. Control 35, 401-406 (2007)

44. S.S. Limaye, C.M. Mastrangelo, D.M. Zerr. A case study in monitoring hospital associated infections with count control charts, Qual. Eng. 20, 404-413 (2008)

45. E. Curran, P. Harper, H. Loveday, H. Gilmour, S. Jones, J. Benneyan, J. Hood, R. Pratt, Result of multicentre randomised controlled trial of statistical process control charts and structured diagnostic tools to reduce ward acquired meticillin resistant staphylococcus aureus: the chart project, J. Hosp. Infec. 70, 127-135 (2008)

46. S Harbarth, C. Fankhauser, J. Schrenzel, J. Christenson, P. Gervaz, C. Bandiera-Clerc, G. Renzi, N. Vernaz, H. Sax, D. Pittet, Universal screening for methicillin-resistant staphylococcus aureus at hospital admission and nosocomial in infection in surgical patients, Jama 299, 1149-1157 (2008)

47. T.L. Wiemken, S.P. Furmanek, R.M. Carrico, W.A. Mattingly, A.K. Persaud, B.E. Guinn, R.R. Kelley, J.A. Ramirez, Process control chart in infection prevention: make it simple to make it happen, Am. J. Inf. Control 45, 216-221 (2016)

48. M. Waterhouse, I. Smith, H. Assareh, K. Mengersen, Implementation of multivariate control charts in a clinical setting, Int. J. Qual. Healthc 22, 408-414 (2010)

49. T. Sanghangthum, S. Suriyapee, S. Srisatit, T. Pawlicki, Statistical process control analysis for patient-specific imrt and vmat qa, J. Radiat. Res. 54, 546-552 (2013)

50. E. Mezzenga, V. D'Errico, A. Sarnelli, L. Strigari, E. Menghi, F. Marcocci, D. Bianchini, M. Benassi, Preliminary retrospective analysis of daily tomotherapy output constancy checks using statistical process control, Plos One 11, 1-12 (2016)

51. T. Fuangrod, P.B. Greer, J. Simpson, B.J. Zwan, R.H. Middleton, A method for evaluating treatment quality using in vivo EPID dosimetry and statistical process control in radiation therapy, Int. J. Healthc Qual. Assur. 30, 90-102 (2017)
52. R. Lee, K. Kim, S. Cho, S. Lim, Lee S., J.B. Shim, H.D. Huh, S.H. Lee, S. Ahn, Statistical process control analysis for patient quality assurance of intensity modulated radiation therapy. J. Korean Phys. Soc. 71, 717-721 (2017)

53. F. Correia, R. Neveda, P. Oliveira, Chronic respiratory patient control by multivariate charts, Int. J. Healthc. Qual. Assur. 24, 621-643 (2011)

54. R. Alsadat, H. Al-Bardan, M.N. Mazloum, A.A. Shamah, M. F.E. Eltayeb, A. Marie, A. Dakkak, O. Naes, F. Esber, I. Betelmal, M. Kherallah, Use of ventilator associated pneumonia bundle and statistical process control chart to decrease VAP rate in Syria, Avicenna J. Med. 2, 79-83 (2012)

55. P.O. Bonetti, A. Waeckerlin, G. Schuepfer, A. Frutiger, Improving time sensitive processes in the intensive care unit: the example of door to needle time in acute myocardial infraction, Int. J. Qual. Healthc. 12, 311-317 (2000)

56. M. Coory, S. Duckett, K.S. Baker, Using control charts to monitor quality of hospital care with administrative data, Int. J. Qual. Healthc. 20, 31-39 (2008)

57. U. Gabbay, M. Bukchin, Does daily nurse staffing match ward workload variability? Three hospital experiences, Int. J. Healthc. Qual. Assu. 22, 625-641 (2009)

58. C. Canel, S. Mahar, D. Rosen, J. Taylor, Quality control methods at a hospital, Int. J. Healthcare Qual. Assur. 23, 59 $71(2010)$

59. T.W. Chien, M.T. Chou, W.C. Wang, L.S. Tsao, W.S. Lin, Intraclass reliability for assessing how well Taiwan constrained hospital provided medical services using statistical process control chart techniques, BMC Med. Res. Methodol. 12, 67-76 (2012)

60. A.M. Spiridonica, The use of statistical process control in pharmaceutical industry, Lucrări stiinţifice. 54, 271-275 (2011)

61. D.R. Prajapati, Correlation level among the observations for a pharmaceutical industry using chart with economics, Int. J. product. qual. manag. 19, 277-300 (2016b)

62. D.R. Prajapati, S. Singh, Determination of level of correlation for products of pharmaceutical industry by using modified chart, Int. J. Qual. \& Reliab. manag. 33, 724$746(2016)$

Cite this article as: Gaurav Suman, Deo Raj Prajapati, Control chart applications in healthcare: a literature review, Int. J. Metrol. Qual. Eng. 9, 5 (2018) 